\title{
The Sustainable Socially Responsible Society: Well-Being Society 6.0
}

\author{
Simona Šarotar Žižek ${ }^{1, *}$, Matjaž Mulej ${ }^{1,2,3}$ and Amna Potočnik ${ }^{4}$ \\ 1 Faculty of Economics and Business, University of Maribor, SI-2000 Maribor, Slovenia; matjaz.mulej@um.si \\ 2 IRDO Institute for the Development of Social Responsibility, SI-1000 Ljubljana, Slovenia \\ 3 IASCYS International Academy for Systems and Cybernetic Sciences, F-64000 Pau, France \\ 4 Regional Development Agency Podravje, SI-2000 Maribor, Slovenia; Amna.POTOCNIK@rra-podravje.si \\ * Correspondence: simona.sarotar-zizek@um.si
}

check for updates

Citation: Žižek, S.Š.; Mulej, M.; Potočnik, A. The Sustainable Socially Responsible Society: Well-Being Society 6.0. Sustainability 2021, 13, 9186. https://doi.org/10.3390/ su13169186

Academic Editors: José Carmelo Adsuar Sala and John Rennie Short

Received: 27 June 2021

Accepted: 12 August 2021

Published: 16 August 2021

Publisher's Note: MDPI stays neutral with regard to jurisdictional claims in published maps and institutional affiliations.

Copyright: (C) 2021 by the authors Licensee MDPI, Basel, Switzerland. This article is an open access article distributed under the terms and conditions of the Creative Commons Attribution (CC BY) license (https:/ / creativecommons.org/licenses/by/ $4.0 /)$.

\begin{abstract}
The purpose of this study is to introduce Sustainable Socially Responsible Society 6.0 as a new concept that is supposed to extend 'Corporate Social Responsibility' to the entire society for humankind to gain a new chance to survive beyond the dangerous neoliberalism that abuses the market and democracy to the benefit of very few humans- the richest one percent and a few around them-and beyond Society 5.0. This study aims to define the framework conditions of 'Well-being Society $6.0^{\prime}$, where humans can both achieve and define their targeted quality of life, including work-life balance, etc. Mulej's Dialectical Systems Theory provides requisite (i.e., sufficient and necessary) integrity/holism of approach that leads to a Sustainable Socially Responsible (SSR) Society without overlooking the necessity of personal, including managerial, responsibility. Most humans try to satisfy their basic survival needs by management, which is requisitely holistic; it can and shall contribute to setting the framework conditions, foremost with non-technological innovation management. The Economy for the Common Good can contribute to SSR Society 6.0, including 'Wellbeing society'. In addition, in 2019-2021 humankind is experiencing the 'new Corona Virus' crisis, killing millions, but also enabling a crucial step toward a well-being society by returning worldwide economic governance from neoliberalism to Keynes-based state capitalism with no loud objections.
\end{abstract}

Keywords: human; industry 4.0; society 5.0; sustainability; social responsibility; sustainable socially responsible society; well-being; 'Well-being Society 6.0'; new coronavirus

\section{Introduction}

\subsection{The Definition of Research Problem}

Rapid information and communication technology (ICT) development is drastically changing both society and the economy. Digital transformation is partly creating new values and is becoming a pillar of industrial policy in many countries. Social problems of modern society are also important, which result from constraints among humans, originating in an aging society, regional disparities and the stagnation of the participation of individuals in social living [1,2].

The impact of digital transformation on society is also addressed by the concept of 'Society 5.0 ', but in other aspects than by 'Industry $4.0^{\prime}$ ', to stop subordinating humans to machines that differ from the machines of the first three industrial revolutions and enhance competitiveness (more in [3-5]). A more humane and therefore requisitely holistic society governance and management is necessary to help humankind find its way out from the current socio-economic crisis that visibly surfaced in 2008 and is not over.

In human history, different stages of the development of society are visible, e.g., in [6,7]. In this societal evolution, Society 5.0 is an information community upgrading Society 4.0 to reach a super-intelligent society [8]. Hopefully, this society will be much more socially responsible and response-able than the current one, in order to develop into a 'sustainable socially responsible (SSR) society 6.0'. 
Society 5.0 seeks to solve problems of sustainable development recognized by Japan, which other countries will also face sooner or later [9-15]. This might be insufficient for humankind to overcome the current socio-economic crisis. 'Well-being Society 6.0' must upgrade Society 5.0 by the application of an SSR society model.

\subsection{Research Question}

For humankind to find its way out from the current global socio-economic crisis, humans need to become, both personally and professionally, socially responsible, practicing sustainability. The extremely rapid advancement of technological inventions and innovations is imposed over current humankind and disregards the natural environment and human nature of humankind. Humans lived in a routine of slow introductions of novelties for millennia before industry, especially Industry 4.0 and Industry 5.0, which are not holistic enough. Therefore, we offer some thoughts on a new concept called 'Well-being Society 6.0 ' as a component of an SSR society, which is connected to some pioneering studies (such as [16-21]) and also to Economy for the Common Good [22-27], and reaching beyond them. We add to $[3-5,25,28-45]$ as economists, working on systems and innovation theory, management and human resources management, applied to social responsibility and to the development of an SSR society beyond neoliberalism and charity, i.e., as a proposal of a new socio-economic order. The latter is unavoidable for humankind to survive $[6,46]$.

Therefore, our research thesis is: The concept of the 'Well-being Society $6.0^{\prime}$ ' can help to create an SSR society based on the advantages of Industry 4.0, Industry 5.0 and Society 5.0 by reaching beyond them.

The interconnections and relationships of all relevant stakeholders (such as private and other companies, the state, trade unions and employer unions) are often ignored in research $[47,48]$. Industry 4.0 is only technology-driven, and it falls short of the systemic, i.e., requisitely holistic, consideration of the human factor that is unavoidable. Due to ignoring the human factor-employees are not motivated, engaged, loyal, successful, can be injured, etc.-people can also lose jobs [49-52] and cannot buy smart products and services. Society 5.0 should solve this problem with a systemic and systematic effort to achieve UN SDGs until 2030 [53], but it is also less holistic than 'Well-being Society 6.0', which should reach beyond SDGs and strive to implement the well-being vision.

Despite numerous advantages, the possibility is considered [54] that Society 5.0's ubiquitous smart systems may create new risks of addiction similar to those already seen in "internet addiction, online video game addiction, and smartphone addiction". Simultaneously, the possibility is explored that Society 5.0's novel technologies might also provide new means for addiction prevention or treatment. The Government of Japan $[55,56]$ adds major cybersecurity concerns that will be provoked by Society 5.0, human participants' diversity and heterogeneity and the integration of numerous viable devices into the Internet of Things. Humans continuously incorporate networked technologies and devices deeply into their bodies, minds and daily routines in Society 5.0, resulting in a "high degree of merging between cyberspace and the real world"; the danger of successful cyberattacks increases, with direct and catastrophic effects on people's lives [55].

If Society 5.0 does not solve issues of Industry 4.0 and 5.0, an SSR society will not be created; the way out from the current global socio-economic crisis will not be found. Therefore, we developed the concept of the 'Well-being Society 6.0'. This is a new alternative to Society 5.0, and thus far, there have been no references on 'Well-being Society 6.0 ' or on a sustainable socially responsible (i.e., SSR) society.

\subsection{Results of the Review of Databases}

In the literature search, the databases dLib.si, ProQuest and Cobbis.si were reviewed in 2020 and 2021. The literature was searched by using the following keywords: Industry 4.0, Industry 5.0, Society 5.0, (corporate) social responsibility, personal responsibility, leadership. We added the literature on the mentioned constructs and systems theory (to 
apply a requisitely holistic/systemic approach), (mainly) only covering publications since 2010. We focused on Slovenian and English languages. Other restrictions were not made.

Information was searched in the databases of the University of Maribor. No book was detected titled SSR society, a single book was detected addressing SR society and a few articles were detected including SR society.

\subsection{Quality Score Review and Description of the Data Processing}

The selected references were mostly published between 2010 and 2020 . We excluded the sources that were doubled or estimated as insufficiently connected in content with the subject, purpose and objective of our research; after the analysis of the technical and scientific content, we conducted a synthesis of the results, and considered the availability of the content and contextual relevance. The search in the databases of the University of Maribor resulted in 5.023 hits. We selected +100 sources and took them into our research.

International scientific literature was primarily considered.

For data processing, see Figure 1.

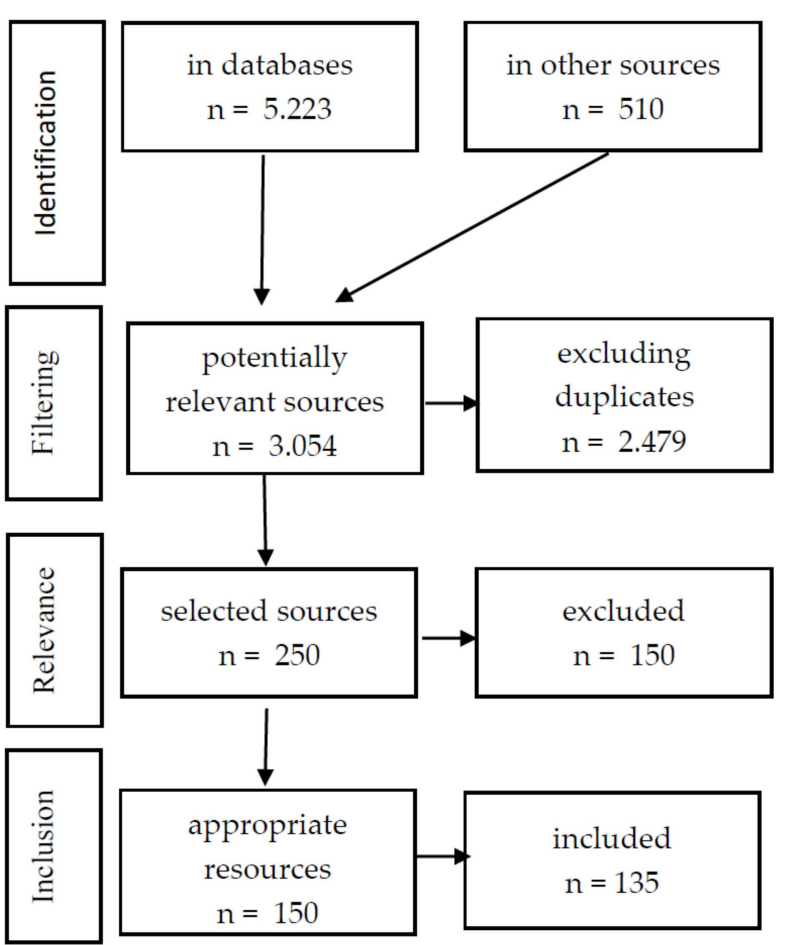

Figure 1. Research process flowchart.

\subsection{Research Methods}

Qualitative research methods included scientific description, induction, deduction, historical methods, analysis and synthesis to answer the research question.

We used scientific description to present theoretical starting points and to describe key facts, processes, techniques and methods relevant to the research of Industry 4.0, Society 5.0 and SSR society, based on a dialectical system of crucial and interdependent aspects.

The comparison method was used to compare facts, phenomena, processes and techniques for individual content sets; it was equally crucial in identifying similarities or differences between the compared findings on Industry 4.0, Society 5.0 and SSR society.

The research was also marked by the modeling method (presentation of individual entire areas of research, such as Industry 4.0 and 5.0), system and contingency theory (determination of the basic research framework) and the method cognitive process. We included methods of deduction and induction. With deduction, we based more significant conclusions about the connection between Industry 4.0, Society 5.0 and SSR society, or between isolated issues and defined research on theoretical starting points. The induction 
supported us to define the significance of the problem at the beginning and to empirically test the research hypotheses, which we defined using the deductive method.

Qualitative research methodology was also based on systems theory [37], Mulej's Dialectical Systems Theory [28], its law of requisite holism [37] and cybernetics.

This paper provides a new non-technological innovation tool to present the socially responsible and therefore sustainable concept of Society 6.0. The paper is based on qualitative research methods (description, compilation, comparison, analysis and synthesis, induction, and deduction) and is structured into several sections. It touches the starting points that are important for Society 6.0; it defines a key concept as a growth and development strategy, strategies and objectives of the concept under consideration and decisions and programs that must be taken by Society 6.0 to extend corporate social responsibility to a sustainable societal one. The last section is devoted to the conclusions.

\section{Theoretical Framework}

\subsection{The 'Well-Being Society 6.0' Concept}

Due to the dangerous dominance of neoliberalism over the free market and democracy, modern society tends to forget about people, nature and their realities, and their interconnectedness (based on interdependence). In doing so, neoliberalism also forgets about the limits of expansive development and the need for the sustainable, long-term existence of humankind; it does not consider the limited and now severely overloaded natural capacity of planet Earth. Research shows that humankind is being forced to be constantly moving too fast and is quickly approaching the moment when we humans will no longer survive $[5,28,29]$.

In order to avoid this blind alley, humankind needs the most comprehensive individuals who, instead of one-sided activities to increase partial well-being, will be able to choose and defend wise, i.e., requisitely holistic, behavior to strengthen the overall well-being of everyone, not just a small percentage of humanity. It is a prosperity that is not based solely on material goods and the enjoyment of them, but on thoughtfully exploited opportunities and resources, an unspoiled environment, satisfied and happy people who live according to their missions and the gifts given to realize these missions. What is important is the most comprehensive quality of life, which is the foundation of a modern society based on prosperity. Prosperity/well-being, which is synonymous with quality of life, depends on: (1) education, upbringing and health; (2) people's living conditions; (3) their daily activities; (4) opportunities for participation in the political process; (5) natural and social environment; and (6) factors that affect the economic, social and personal security of people [46,57-59]. All these and further preconditions and conditions of life are created, mostly not provided by nature; therefore, they depend on behavior, governance and management.

'Well-being Society 6.0', defined this way, is a part of an SSR society in which all, not only business, organizations practice all three basic postulates of modern society, expressed by humankind in ISO 26000: responsibility for influences on society, interdependence and (requisite) integrity/holism. Humans and their organizations support such attributes by practicing the seven principles of social responsibility that humankind has agreed upon in ISO 26.000 [60]: accountability, transparency, ethical behavior and respect for stakeholders' interests, for the rule of law, for international norms, and for human rights.

An SSR society, including 'Well-being Society 6.0 ', is based on the synergy of: Industry 4.0 [61-64] and Industry 5.0 [65]; Society 5.0 [2,8,10-13,60,66,67]; the United Nations' SDGs and other critical goals; personal, organizational and societal social responsibility $[1,9,28,30,67-71]$; fighting disregard for the environment by taking the natural environment into account as a crucial precondition of humankind's survival, etc. All influences support the development of an SSR society [5]. Given many references, we will not summarize the available information. See $[61,62,64,72-81]$.

We must only mention five 'Key Concepts' concerning the human factor (HF) that can provide the basis for understanding the interrelation of Industry 4.0 and the HF [81]:

- Key Concept 1: Industry 4.0 systems are socio-technical systems. 
- $\quad$ Key Concept 2: Attention to the HF must occur throughout the design.

- Key Concept 3: Human-system interaction engages perceptual, cognitive and motor systems.

- Key Concept 4: People have psychosocial needs.

- Key Concept 5: Organizations tend to "drift to unsafe states".

For the effective and efficient adaptation of Industry 4.0, industrial companies need people with different skills and competencies; appropriate technical infrastructure; openness to changes [82].

Industry 4.0 and Society 5.0 are connected because many technologies that have already changed the industry have an important role to play in transforming society; Industry 4.0 is developing to become the concept of Society 5.0 [83]. This concept [83]:

1. Takes into account current social and technological challenges in the direction of the humanization of society;

2. Is a socio-economic and cultural system that is steadily developing in an optimal direction for humanity based on the processing of Big Data Results (i.e., many more data than so far), enabling more holism of behavior.

In the current age, society faces a big difference that results from globalization andmostly un-holistic - use of cybernetics (as a science of mastering complex natural, technical and social processes) and systems theory (as a science of maximizing holism in dealing with anything instead of excessively narrow and biased specialization) (more in: [31]), also for the rapid development of digital technologies (e.g., the Internet of Things (IoT), artificial intelligence (AI) and robotics).

Environments-natural, work, social, societal-are changing, and thus the dominant parts of people's values, culture, ethics and norms (VCEN) and habits are changing (habits are added by Štrukelj [84].); the direction is not clear: it is not unavoidably SSR society. People are facing challenges of global dimensions, such as the depletion of natural resources, global warming, increasing economic incompatibility, terrorism, etc. (According to several reports in public media, the European level of consumption, i.e., destruction of natural resources, right now requires close to three planet Earths, and the consumption of the richer USA requires even four planet Earths. In only twelve years from now, Earth may exceed the livable $\mathrm{CO}_{2}$ concentration. An SSR society seems to be the only way to survive. SDGs must become a practice, not only guidelines, e.g., [85].) Their common denominator is one-sided instead of systemic, i.e., appropriate, treatment of people [5]. Therefore, uncertainty and great complexity prevail. This is why it is very important to focus on harnessing ICT to acquire new knowledge, create new values/VCENH, such as ethics of interdependence and requisite holism and social responsibility, including connecting people to things, as well as the real world with the cyber world. These links should be effective means of addressing social issues, creating better lives for everyone (not just material wealth beyond needs) and maintaining healthy economic growth [8].

In December 2015, Michael Rada developed an initial idea called Industry 5.0 [86]. By the implementation of the Industry 4.0 concept, full automation should be introduced in manufacturing to replace the dehumanization of the work process in which humans would be redundant. Humans should return to the production process, but in another way, based on new technology, specifically collaborative robots-so-called cobots. Industry 5.0 also provides customer-tailored products $[65,87,88]$.

Industry 5.0 is the next step in evolution $[49,83]$. For example, the current COVID-19 pandemic crisis might be solved with Industry 5.0 technologies, but less so can be Society 5.0 or even SSR Society 6.0 ; they do not depend on technology alone [89].

The Japanese Business Federation envisions that in Society 5.0, every human, including elderly people and women, can live a safe and secure, comfortable and healthy life and each and everybody can realize his/her desired lifestyle full of well-being [7,65,90,91].

The implementation of Industry 4.0 and Industry 5.0 is the basis for designing a new cyber-physical environment with better connections between people, things, humans' subjects and technologies in an advanced cyberspace environment and is the basis for Society 
5.0 [10-13]. Authors such as $[12,14,92]$ disclosed that advanced technological solutions create infrastructures with added high-value information; this enables responsible cooperation of people, things and technologies in modern society. Technological development provides useful technological solutions for very many products and services, which can match responsible demands in society $[12,32,93]$.

\subsection{Society 5.0}

Society 5.0 is a strategy and a central concept introduced in Japan's Fifth Basic Plan for Science and Technology, adopted by the Japanese government in 2016 under the sponsorship of the Keidanren Japan Business Federation and seen as a core growth strategy. It is based on recognized underlying problems, limiting the sustainable development of the Japanese and global economies, which negatively affects the state of society.

This means that Japan is already facing challenges that many other countries will face sooner or later, such as an aging population, declining birth rates, and aging infrastructure. Japan was one of the first countries to address these challenges; through its way of dealing with them with the help of Society 5.0, it can contribute to addressing such and similar challenges worldwide and achieving UN SDGs [8]. Japan also used it to solve these problems as a basis for creating a super-smart company of Society 5.0 under the auspices of the Keidanren Japan Business Alliance [10].

In Japan, governmental agencies, universities and businesses are actively working together to develop and implement the Society 5.0 paradigm $[55,94,95]$. Thus, Society 5.0 is a Japanese growth strategy that is not limited to Japan, since the goals are in line with the UN SDGs as presented in the UN 2030 Agenda. At the United Nations Conference in New York in September 2015, world leaders pledged to eradicate poverty and prevent climate change and injustice. The 2030 Agenda for Sustainable Development grants a better future for the planet and billions of people around the world; 193 countries unanimously adopted 17 UN SDGs, which have become the new universal developmental standard. The primary purpose of the SDGs is to ensure inclusiveness. The SDGs' background indicators provide clear benchmarks, measuring performance [85].

Society 5.0 followed the previous development visions with the consideration of responsible economic development [96] and solving sustainability issues [9]. Society 5.0 complements the social orientation of corporate social responsibility (CSR) of organizations with content-related and methodological frameworks for the creation of innovative solutions and guidance designated for solving urgent social problems in modern society [66-68]. Society 5.0 is the basis for an SSR society, including the new 'Well-being Society 6.0'.

Society 5.0 considers Industry 4.0-and its new technologies—-for sustainable societal development $[32,67,97,98]$. It reaches far beyond it, but not far enough: its common denominator is still growth, which the natural environment no longer enables.

Society 5.0 is a socio-economic and cultural system/arrangement/order that is sustainably evolving in a direction that is hoped to be optimal for humanity. Development is driven by the processing of Big Data Statistics, where physical and cyber spaces are becoming an integral whole for solving societal problems by enabling security and innovation-friendly and eco-friendly growth [98]. As [99] notes, the aim of Society 5.0 is nothing less than the "creation of equal opportunities for all and also providing the environment for realization" of each individual's potential; to that end, Society 5.0 will employ emerging technologies "to remove physical, administrative and social barriers to self-realization of the person". Society 5.0 is an initiative that seeks to create a sustainable society for human security and well-being through a cyber-physical system [100] and is not only a political-ideological idea; it is by all accounts important to coordinate measurements such as (1) Innovation Policy (from the government side), (2) Entrepreneurial Soul (from the society side) and (3) Entrepreneurial Skills (from common society and organizations) [101].

The concept of Society 5.0 focuses on achieving UN SDGs until 2030 [98]: conscientious consumption and production, sustainable cities and populated areas, industrialization, innovation and infrastructure, affordable (cheap) energy, good health and well-being, etc. 
Leading industry corporations are determined to actively disseminate the ideas of Society 5.0 worldwide [98]. This means that the aim of Society 5.0 is also to create a human-centered society [8,95]. However, the possibility of new risks remains, such as new addictions [54], although Society 5.0's novel technologies might also offer new means for preventing or treating addictions.

The Government of Japan $[55,56]$ also recognizes major cybersecurity concerns that will be exacerbated by the diversity and heterogeneity of human participants in Society 5.0 and the integration of growing numbers of devices into the Internet of Things. As human beings incorporate networked technologies and devices ever more deeply into their bodies, minds and daily routines in Society 5.0-resulting in a "high degree of merging between cyberspace and the real world" — the danger increases that successful cyberattacks might have direct and catastrophic effects on people's lives [55].

Hence, SSR Society 6.0 seems possible and needed, but not unavoidable and quickly attainable.

\subsection{Goals and Strategies}

The Government of Japan formulated guidelines to guide the implementation of the UN SDGs as follows: science, technology and innovation (STI). Guidelines in these areas are the cornerstone of achieving the set UN SDGs, and therefore Society 5.0. STI also shaped key policy and priority areas. The Japanese government formulated key policies and priority areas [12]: creating a global future with Society 5.0; enabling solutions using global data; promoting global cooperation; and promoting human resources to implement guidelines to achieve the UN SDGs. The twelve service platforms will be fully developed using the Internet of Things and create smart companies (IoT) [12].

To achieve a global SSR society as quickly as possible, it will be necessary to create a common ecosystem that brings together ideas from the economy, science and individuals [12]. Since one of the goals of Industry 5.0 is to strike a work/life balance, companies play a very important role, too. Incorporating CSR practices includes community-oriented actions such as donations, volunteer work and sponsorships towards the environment, such as the use of clean and renewable energy sources and a reduction in energy consumption and emissions [102].

There are programs that companies must follow to (identify and) achieve the goals of Society 5.0; only some of them are highlighted here [99].

\subsubsection{Ecological-Environmental Program}

An example of an ecological program is "Clean Air, Clear Water, Net Food, Net Energy, Net City and Village, Net Nature"; see its aim in $[99,103]$.

\subsubsection{Economic Program}

An innovative eco-development program must take into account the resources of the national (or regional or sometimes even global) economy through budget execution, innovation, investment and self-supporting and self-funded economic processes, which are proportionate, integrated, approved in a timely manner and territorially positioned in industries. Implementing such a program will reduce employee stress [99,103-105].

Responsible humans on different levels in the hierarchy must develop diligent groundbreaking offers and flexible taxation to abolish social and economic stress in society, repeal the authority of the government and advocate the statement of justice in society $[99,106]$.

To ensure the social and economic stability of the government of a country, the authorities of regions and cities, together with the departments and enterprises of different branches of the economy, the balance sheets of the states, regions, cities and their inhabitants are important to financially, etc., ensure the production of products, goods and the provision of services that contribute to healthy individuals and society. The state sets fiscal rules for corporations to provide every conscientious employee with a salary, which should not be less than the monthly cost of products, goods and services needed for a healthy life 
and business. Strategic priorities for innovative health care in the whole economy include:

(1) constant supply of the population with goods, services and conditions for healthy living;

(2) supplementing resources; and (3) environmental ecology. Supplying the population with starting points in the social and economic norms of a healthy life is driven by uniform pricing in terms of meeting future demand for the ability to live healthily $[99,103-105]$.

\subsubsection{Social Program}

A healthy nation develops based on a healthy lifestyle. The transition to a healthy lifestyle takes four stages [99]:

(1) Mastering a lifestyle to restore and maintain the acid-base balance of the biological environments of the organism;

(2) Developing improved abilities at the level of spirituality, strength, physiology and anatomy to achieve a healthy state;

(3) Acquiring skills to maintain a healthy body/mind state;

(4) Gaining experience with behaviors consistent with a healthy lifestyle that maintains health in different living, social and natural seasonal conditions (spring, summer, autumn and winter), to maintain a healthy state throughout the year.

Japan promotes the development of human resources as it seeks to establish a society in which everyone (regardless of age, gender, disability) will have the opportunity to live a full life and demonstrate their skills. It is therefore all about a society in which every individual can be actively involved [107].

For the development of peaceful, humane policies, it is necessary to [99]:

- Directly manage organizational efforts and material resources toward human development and the creation of a healthy, professional culture of civil society;

- Develop peaceful, humane diplomacy;

- Develop a healthy lifestyle as a cultural tradition to keep the current and the next generations healthy;

- Involve cultural and spiritual institutions, including religious institutions, in shaping a healthy culture of professional and civil society;

- Create an infrastructure for a self-managing professional culture of a healthy civil society;

- Move towards a society-oriented eco-economy whose initial arrangement is the regulation of a healthy person.

Peaceful human politics shapes the worldwide culture. The prevailing culture of the world strongly calls for the creation of a world accepted by all. The worldwide culture needs the development of counterbalancing skills to learn how to work with one another and overcome blockages through ultimate confrontation. Therefore, humanity is committed to respecting diversity, turning competition into cooperation based on shared values and goals through dialogue, mutual understanding, calmness, assent and solidarity [99]. This process leads to a sustainable socially responsible (SSR) society [5] by the diffusion of corporate social responsibility to (more or less) everybody and every body of society.

According to Japan, to achieve a medium- and long-term growth period, it is necessary to realize the Society 5.0 concept, the essence of which is the aim to solve societal challenges. It contains the technological innovations of the 4th Industrial Revolution, too, which have quickly spread to almost every industry and almost every part of social life.

In Japan, governmental agencies, universities and businesses are actively working together to develop and implement the Society 5.0 paradigm $[55,56,94]$. Thus, Society 5.0 is a Japanese growth strategy that is by no means limited to Japan, since the goals are in accordance with the UN SDGs.

This means that Japan's Society 5.0 initiative is (partly) founded in the 'Industry $4.0^{\prime}$ paradigm $[62,108,109]$ that was initially developed in Germany in the early 2010s. The Industry 4.0 paradigm is understood as focusing on the creation of the 'smart factory' $[110,111]$, but Society 5.0 is geared toward creating the world's first 'Super Smart 
Society' $[55,56,95,99,111-113]$ by the "creation of equal opportunities for all and providing the environment for realization" of each individual's potential; accordingly, Society 5.0 will employ emerging technologies "to remove physical, administrative and social barriers to self-realization of the person". Gradually, it may come close to an SSR society. Thus, Society 5.0 is important for solving significant ecological, economic and also social problems in the present society, caused by a longer lifespan, aging societies, the concentration of wealth and regional inequality $[13,15]$. Still, it is exposing growth more than humans' free time content.

The concept of Society 5.0 focuses on achieving the UN SDGs, until 2030 [98], only.

\subsection{United Nations Sustainable Development Goals}

At the United Nations Conference in New York in September 2015, world leaders pledged to eradicate poverty and prevent climate change and injustice. The 2030 Agenda for Sustainable Development thus offers a possible way to a better future for billions of people around the world and our planet as a whole. A total of 193 countries unanimously adopted 17 Sustainable Development Goals (SDGs), the new universal standard for development. The primary purpose of SDGs is to ensure that no one will be left out. The SDGs' background indicators provide clear benchmarks for measuring performance [85].

For humankind to realize the Society 5.0 concept and reach beyond it, we suggest 'Well-being Society 6.0' as a requisitely holistic concept (in which well-being reaches far beyond charity), a part of SSR Society 6.0 [5]. It has not been normal so far, and it must therefore be integrated in organizational and societal governance [33,34] and in education (especially in higher education) [35,36]. For more information, see [10,114-117].

«Beyond its human members, Society 5.0 can be expected to include many types of non-human intelligent social actors as 'participants' or even 'members'» [112]. The future Society 5.0 can be understood as 'post-humanized' insofar as it is a vast, complex cyber-physical-social system that encompasses more than simply natural biological human beings as members and participants [112].

Society 5.0 is also connected to the danger of underestimating and misunderstanding the consequences of upcoming social changes and their unpredictability. Therefore, it should be based on a new social formation, its benefits, risks, promising tasks and new approaches to behavior and management from the positions of politics, governments, business, etc.

\section{Results Called 'Well-Being Society: A Core Component of Sustainable Socially Responsible Society 6.0'}

Methodologically, we based SSR Society, including Well-being Society, on Mulej's Dialectical Systems Theory (DST) [28], its law of requisite holism [37] and cybernetics.

A few years before Mulej's DST and 2nd order cybernetics, Bertalanffy published his General Systems Theory (GST) [118,119], where he included a crucial statement on page VII in Foreword: GST was created to fight the practice of exaggerated specialization in order to attain a holistic approach and wholeness of outcomes. The point of Systems Theory is to fill in the empty spaces between findings of other disciplines by enabling interdisciplinary creative cooperation, creating synergies of insights and preventing oversights. This was the approach used by Wiener to create cybernetics-see $[120,121]$. It is rare (too bad).

Mulej's other dissatisfaction was the notion that economics, management and organization deal with the realization of objectives, which may be desired. Rarely, if ever, desires can be well-grounded-requisitely holistic, especially if not linked with a systems approach. Failures unavoidably occur. DST offered the solution.

Requisite holism and interdependence are central and poorly covered in the criticized practice. This is why Mulej's theory is called Dialectical Systems Theory and is aimed at the dialectical system as the synergetic network of both necessary and sufficient, i.e., requisite, viewpoints/specializations. DST is thus a specific methodology of requisitely holistic behavior. It includes three relations and three components of DST [37].

Cybernetics is the science of effective influencing, including organizing, that shapes organizational modes so that they are able to adapt to a changing society and its institu- 
tions [44]. The 'viable system theory' applies it, with a special set of structural invariants in all such systems [122,123].

If society is an organized whole, when can it be considered viable, that is, capable of surviving in the long run? It has to be (very) self-sufficient, first. For this end, a society must provide the framework conditions for members' self-sufficiency by a shared self-sufficiency chain, and at least in part, enough customers in the society. It follows: the society supports such programs and projects that directly contribute to self-sufficiency. However, how do we choose between diverse interests? What should be the measure and criterion of selection? [44]. Given human nature, these issues will hardly disappear in Society 5.0 or the new type of 'well-being society' (i.e., way beyond neoliberalism and charity, etc.) on humankind's way to SSR Society 6.0.

SSR Society 6.0 can also solve the final challenge of COVID-19, which has exposed the new political economy of SSR society. "On the one hand, COVID-19 has re-centered governments as the key actors in tackling grand challenges rather than being seen as increasingly ineffective in this space, as they are often portrayed in the SR literature. On the other hand, it is clear that the social responsibility of companies in the pandemic has been to act along with governments (and other actors) to address the pandemic - not so much by voluntary, charitable good deeds (although these have also played their role) but by employing (and safeguarding) workers, producing socially useful products, and protecting their stakeholders. As such, COVID-19 questions the core purpose of what a firm is about and what role it should play in society ${ }^{\mathrm{TM}}$ " [124].

First, society is a complex organizational structure, more precisely a synergetic network of its inhabitants. Complicated? To the extent that the organizational structure can handle this, we people simplify until we threaten the viability of the organization, humans and society too much. Complexity, however, reminds us that we are dealing with a relatively high number of viable humans, connections between them and with their diversity. As early as the 1970s, this appeared to be an obvious organizational shift [125], a horizontal (and not merely vertical or command-down) appropriateness. Complexity manifests itself as a complementary process of differentiation and increased interdependence between people [126-128]. In principle, we can take humans' opinions into account, 'play' elections or opinion polls and find out how much they love on average, e.g., a particular government. Can we measure differently? Let us see how this is performed by cybernetics (focused on human relations, rather than technology) [44].

Beer [129] points out that people need a measure of success that is less "charged" with emotional urges for profit, but more justified by risky resources, while expressed in sufficiently general metrics applicable to the entire organization. If money is not a unit, then numbers are. The levels of achievement therefore depend on:

- Topicality: what a team is managing now, with existing resources and within existing conditions; planning on the basis of topicality is called programming by Beer.

- Ability: what a team could achieve now, with existing resources and under existing conditions, if one chooses to do so; capability-based planning is called planning with goals by Beer.

- Potentiality: what a team could achieve with one's own resources and after removing the barriers, even though within what appears to be possible. Potential-based planning is what Beer calls normative planning. However, Beer points out that no matter how one plans, what actually matures is topicality.

The measures of the relationship between topicality, ability and potentiality are:

- Latency: the relationship between ability and potentiality;

- Productivity: the relationship between topicality and ability;

- Performance: the relationship between topicality and potentiality. (ibid.)

Measures can change constantly. They can be used to measure the entire organization or the efficiency of an individual department or an individual activity; they can be used for various aspects of work-for the effect of the workforce and for the technological capacity 
of, e.g., a factory. In these cases, partial indicators can be multiplied or used as a total measure of performance, consistent with the calculation of bare data. All three performance measures should increase [44].

For our research, a new synergy of the dialectical systems, living systems, and viable systems theories is also important as potentially complementary systems theories and three methodologies supporting informal requisite holism of thinking, decision making and action. This methodology is optimal for the public sector [45].

\subsection{Dimensions and Components of the New 'Well-Being Society 6.0' Model}

The new 'Well-being Society 6.0 ' as a part of the SSR society is the next step after Industry 4.0 and 5.0, the SDGs of the United Nations, Society 5.0, the three postulates and the seven principles of social responsibility from ISO 26000; it enjoys all (political, economic, legal, social, health, ecological, etc.) systems well developed as necessary for the functioning of society. These are the foundations with which influential persons and organizations and societal bodies then influence the people and their organizations that manage business processes, to match key performance indicators (KPIs), leadership, principles and systems of Industry 4.0 and 5.0 within the organization including human resource management. We presented this in basic form in Figure 2 and then upgraded it in Figure 3.

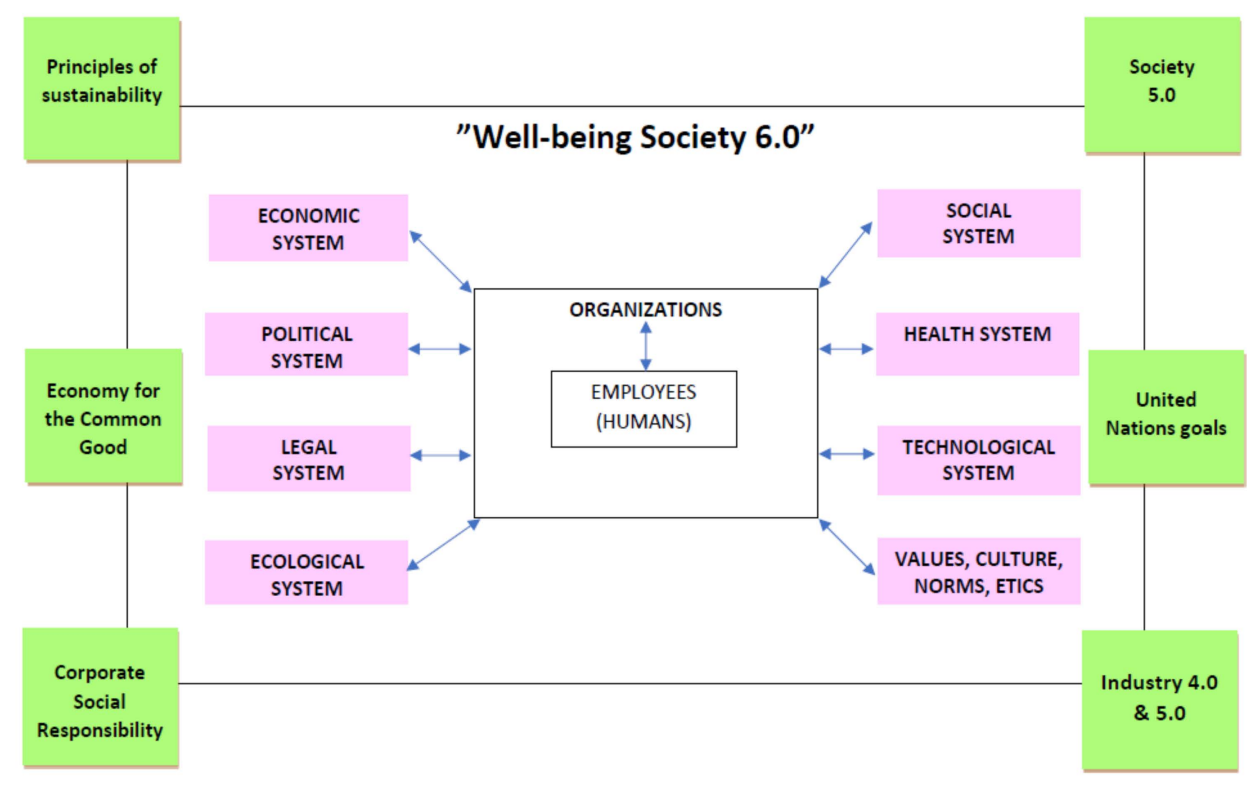

Figure 2. Basic concept of the new 'Well-being Society 6.0'.

N.B. The frame depicted in Figure 4 has two more not depicted frames: the unconsidered and the considered environment of the considered society.

Thus, the dimensions of well-being in a "well-being society" include: (1) income and assets, (2) work activities, (3) housing conditions, (4) education and upbringing, (5) health, (6) security, (7) consideration, (8) social cohesion, (9) political voice and governance, (10) natural environment. Therefore, well-being must be a synergy of material well-being (income and wealth, employment), social well-being (education, upbringing, health, safety, consideration, social cohesion, political voice and governance, life satisfaction) and environmental well-being (healthy natural environment) [46,57-59]. 


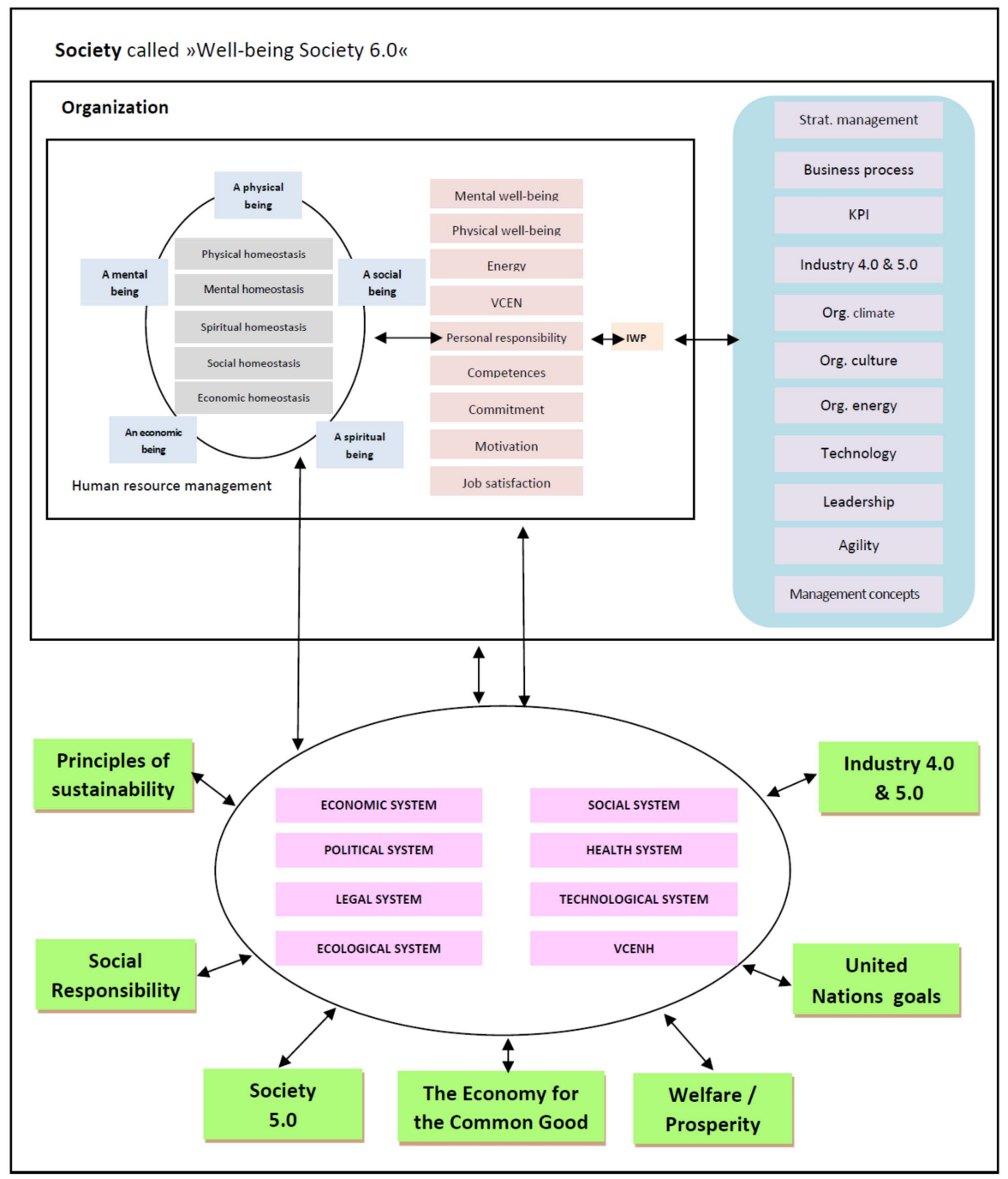

Figure 3. Upgraded concept of the new 'Well-being Society 6.0' (IWP-Individual work performance; VCENH—Values, culture, ethics, norms and habits; KPI-Key performance indicators).

'Well-being Society 6.0' enables everyone's harmony with everything, attained through scientifically tested methods that have been proven to provide results, and innovation (technological and other). This compliance or harmony is the basis for harmony on the one hand and for the most comprehensive/holistic action possible, which is not harmful to anyone, but rather satisfying all, on the other hand.

\subsection{The Foreseen Path to the Establishment of 'Well-Being Society 6.0'}

We model the path to the establishment of 'Well-being Society 6.0'; it is complex, but less complex that the consequences of the current neoliberal monopolistic practice abusing the free market and democracy [130]. 'Well-being Society 6.0' is based on pioneering contributions (e.g., [16-21,28,38] and others) because they have offered valuable research challenges and contributions on developing and consolidating knowledge and designing/developing practical strategies for enforcing SR in national societies and the global community. The suggested model is based on the idea of The Economy for the Common Good, which represents an alternative to both capitalism and communism and is based on a requisitely holistic worldview [22-27] (in synergy):

- Preserving nature and the natural environment in all its dimensions;

- Happy, personally and socially responsible, response-able, respected, competent and satisfied people whose lives are fulfilled in symbiosis with each other and with 
nature as a whole; they can also express themselves creatively (in organizations or within entrepreneurial initiatives as well as voluntary activities);

- State-of-the-art technology (automation and robotics, digitalization) to support humans in creating goods (products and services) to meet their needs while ensuring human safety and health;

- Properly structured and organized family as the basic cell of a society that often also functions as an extended family, in which not only the care of children and adolescents is exposed, but also the elderly, who are sages from whom both family and society draw wisdom, but may need help. The family is dominated by harmonious interpersonal relationships and mutual assistance;

- The participation of people in society and in organizations, as individuals are competent and also highly developed and are therefore able to act autonomously or as a team, including for the benefit of society;

- Long-term business success of organizations, as all stakeholders, especially managers as the most influential ones, strive not only for short-term but for long-term success of organizations while preserving the nature and dignity of the individual (including as an employee). Managers are highly qualified (competent) for their work, socially responsible according to their values, and they are chosen not only by the owners, but also by the employees. Owners and employees assess their way of working as well as the strategic development program of the organization's managers submitted for consideration, and assess this as appropriate from all relevant aspects and their synergies. However, managers are assessed not only in terms of achieving their goals and their approved development program, but also in terms of their personal and socially responsible conduct;

- Responsible owners who have the energy, knowledge and awareness of what and how to optimally co-manage people, their organizations, and thus indirectly, society;

- VCENH (values, culture, ethics, norms, and habits), which are socially responsible and therefore the foundation of human activity and are systematically developed in a society [37,84];

- Thoughtful consumption, not consumerism, i.e., not based on glorifying material values, when people buy (in excess) expensive cars, clothes and other new products for their own (short-term?) happiness because they are convinced that buying new and better products brings happy emotions, a good image and popularity. It should also be borne in mind that it does not make sense to let desire for material goods grow faster than the income that individuals receive, without limits. Therefore, even if their income has increased, it still does not meet the desire of insatiable people with inferiority complexes for non-essential material goods, which makes individuals less happy, or a higher income does not reinforce the expected feeling of happiness beyond sustainability. Some researchers find that people with higher incomes are happier than those who receive lower incomes, but the level of happiness in people with higher incomes does not grow despite rising incomes-on average, it is proved to be constant [28];

- Diversity management - this is about being different from each other, but still representing a unit. Each individual is a piece of a large mosaic. This means that diversity management is about being aware (with regard to gender, age, ethics, education, residence, etc.) of the differences between us, and acceptance of and respect for differences;

- $\quad$ UBI-universal basic income;

- Solidarity - in terms of caring for each other, regardless of any differences between people;

- Time, a good that normal persons lack, and therefore a 'Well-being Society 6.0' provides people with 'free time' with a shorter time to perform individual tasks, but not at the expense of quality. (In 150 years, the weekly working time was reduced from 100 to $40 \mathrm{~h}$, and in some places to 30 , with the problem being only the content of free 
time.) Leisure is more than an important value. Technology allows people more and more free time and aware people use it, e.g., for:

(Personal and personality) development,

Strengthening competencies, values of social responsibility and consideration, Strengthening physical, mental and social health,

Creating harmony and inner fulfillment,

Creativity, which is a precondition for creating a new day,

Active participation in public affairs,

Visualization of new things, products, services and other innovations,

Healthy hobbies, such as sport,

Tourism, etc.

- Systems/orders/arrangements, such as political, legal, economic, social, health, etc., which form the foundation of 'Well-being Society 6.0';

- Democracy. From the multitude of records on democracy, we would like to point out two questions that it makes a lot of sense to raise again: (1) What (everything) is democracy? (2) What is the situation in this light in, for example, Slovene political life? We connect them with the thesis that, according to the Constitution, the parliament is the supreme body of social care for a Sustainable Socially Responsible Society, i.e., for concern (not as worry, but as practical action) that every essential action is based on responsibility to society, i.e., to people and nature, on interdependence and integrity/holism. With the basis that they started introducing democracy a long time ago, against the abuse of power. Therefore, it is far too one-sided if people understand democracy by the number of parties and/or votes, which is expressed by popular wisdom with the joke that in 'a democracy the voice of two fools is more important than one of the smart'. It is about the social responsibility of all influential people, especially the ruling ones. Humankind defined this in the documents of its global bodies - the United Nations and the International Organization for Standardizationmost succinctly in 2010 with the ISO 26000 advisory standard: social responsibility is a way out of the crisis that is imposed on the whole world (except a small percentage of the richest) by neoliberalism that destroys the market economy and democracy through monopolies. The European Union immediately committed itself to supporting social responsibility and called on EU Member States to adopt a social responsibility strategy [131]. Restricting democracy to elections (which cannot be avoided) and to the right of everyone to express their opinion is clearly too little. Governance and public speaking must be performed with personal and social responsibility. The more influential someone is, e.g., as president of the state, government, party, minister or his/her associate, judge, mayor, member of the National Assembly or similar body, owner or manager of a company or something similar, the more he/she must act according to ISO 26000 (without its restriction to corporations). Europe as our common home is bursting at the seams because many politicians see elections, not VCENH, of democracy as part of social responsibility. They think too narrowly and too short term to lead the people out of a crisis instead of causing the crisis by a shift from meaningful patriotism to dangerous chauvinism and the like.

- Well-being organizations are organizations that care for the well-being and welfare/prosperity of all other stakeholders. Such organizations are managed by wellbeing managers.

These components are interdependent and synergetic, of course.

\subsection{VCENH That Contribute to the New 'Well-Being Society 6.0'}

The realization of the briefed model depends on humans, of course. Hence, the following attributes are included in VCENH of democracy because they contribute to 'Well-being Society 6.0 ', in particular $[39,84,132]$ : 
- Freedom-once from the war, today from the financial, business and bureaucratic occupier (which turns $99 \%$ of humanity into a neo-colony without real freedom);

- Peace and coexistence between nations/peoples-instead of pointless conflicts all the way to destructive and deadly wars for the benefit of arms manufacturers, outside their homelands;

- Comradeship-mutual consideration and joint resolution of dilemmas instead of too much selfishness;

- Solidarity—public education, public health, social insurance, etc., without abuse;

- Equality - the contribution of professional work to the success and risk of the organization is already at $85 \%$, and the contribution of capital is only $15 \%$, so the owners of capital should not decide alone;

- Freedom of religion - the separation of religion from the state and the relative equality of all religious communities, but who should abandon the claim that their religion is the only right one, instead of coexistence;

- History without falsification of facts and biased interpretations, no war collaboration;

- Security-without un-holistic privatization and politicization;

- Quality of government (or the quality of "governance");

- The power of the people-not the power of the parties with an order to raise their $\mathrm{MPs}^{\prime}$ hands instead of comprehensive arguments in parliaments, in the earlier stages of the legislative process and in the implementation of the rule of law and sustainable social responsibility as an upgrade of it;

- Action-rebellion, the success of the uprising, liberation and the precious 'Europe Day' do not come by waiting for others to take care of our interests, rather than their own narrow and short-term ones;

- Social responsibility—as a personal characteristic that everyone accepts responsibility for the consequences of their influences on society, i.e., on people and the natural conditions for survival, cultivating an ethic of interdependence and striving for maximum integrity/holism through interdisciplinary creative collaboration;

- Ability and willingness to understand and consider in practice that power does not give special rights and privileges, but adds a duty to do more for the common good than others, more responsibility and no right to irresponsibility;

- Ability and willingness to understand and consider that we are all interdependent and influence other people and activities, as well as the natural environment;

- Ability and willingness to understand and consider in practice that any activity can also be dangerous for the natural conditions of the survival of the current civilization and the coming ones. (In spring 2021, the German Constitutional Court of Law proclaimed the lack of environmental care unconstitutional because it burdens the coming generations. This actually matches Gro Grundland's UNO definition of sustainable development by which the current generation may not endanger the later generations' possibility to cover their needs.) This is also why maximum integrity/requisite holism is essential;

- Etc. This is democracy, not an election that only gives tasks to the elected to take care of democracy and us citizens. Additionally, the existence of several parties is not enough (perhaps not always a necessary precondition) if it enables or even strengthens one-sidedness instead of integrity/holism with responsibility for influences and interdependence, i.e., with social responsibility.

'Well-being Society 6.0' is a part of the SSR society in that all organizations, not only business organizations, practice all three basic postulates of modern humanity, expressed in ISO 26000. The first postulate is the responsibility of everyone for influences on society, i.e., people and nature (instead of the right to irresponsibility of influences because they are untouchable, and others because they are uninfluential). The second postulate is interdependence (instead of the imaginative opinion of the influential that they are independent and no one can do anything to them, and the modest opinion of the uninfluential that they are dependent and can do nothing to anyone), and the last is integrity/holism—as much 
as possible-instead of one-sidedness and bias, which due to the necessary narrow specialization is associated with a harmful lack of ability and willingness of interdisciplinary creative cooperation of mutually different specialists [133].

They are supported by the qualities that prevail in people, in organizations and in society as a whole, and according to ISO 26000 [133], humanity expresses them as principles of social responsibility. The first is accountability prescribed by fair law, which prevents the abuse of people and nature, while social responsibility complements law, or becomes law. Next are transparency instead of concealing essential data, in particular information as influential data, and ethical conduct, based on the values of fairness, justice and integrity, care for people, animals and plants and other natural resources, including levels beyond the letter of the law. Respect for the rights of stakeholders (not just owners and their governing proxies, as they are interdependent with others and more easily achieve greater integrity and responsibility of themselves, towards themselves and towards society), respect for the rule of law (of course not monopolistic law and without looking for holes instead of the essence), respect for international norms (which are the laws beyond state and local laws, of course not monopolistic, and with taking into account the essence instead of looking for holes) and respect for human rights (globally defined by documents of the United Nations and other global organizations of humanity, such as UNESCO, WHO, ILO, etc.) are important.

\subsection{Way to Implement 'Well-Being Society 6.0'}

The basic reasons for the new 'Well-being Society 6.0' as an attribute of an SSR society include the unavoidable end of the very dangerous dominance of neoliberalism over the free market and democracy. Neoliberalism makes modern society forget about humans, nature and their givens, and their interconnectedness/interdependence. In doing so, its power-holders also forget the reasonable limits of expansive development and the need for sustainable long-term existence; they do not consider the limited and now severely overloaded natural capabilities and possibilities of planet Earth. Therefore, the current generation of humankind constantly 'drives in the overtaking lane'. That is why humans are fast approaching the moment when we will ask ourselves whether an acceptable tomorrow will come at all, or the end of humankind. In order not to face this threat, humans need the most comprehensive/holistic approach (or: individuals who, instead of one-sided activities to increase partial well-being, will be able to choose and defend well-considered decisions to strengthen the overall well-being of all, not just a small percentage of humanity). It is a prosperity that is not based solely on material goods and the enjoyment of these, but on thoughtfully exploited opportunities and gifts, an unspoiled environment, satisfied and happy people who live according to their mission and the gifts given to make life happy. What is important is the most comprehensive quality of life, which is the foundation of a modern society based on prosperity. Prosperity, synonymous with quality of life, depends on: (1) Education, upbringing and human health; (2) People's living conditions; (3) Their daily activities; (4) Opportunities for participation in the political process; (5) Natural and social environment; and (6) Factors that affect the economic, social and personal security of people.

It is also important that 'Well-being Society 6.0' is based on personal and corporate and SSR Society and sustainable leadership and sustainable leaders. Here, there is no more room for details about them; we will consider them as a part of the special topic on such leadership. We present the following output of 'Well-being Society 6.0': (1) Sustainable personal and corporate and societal social responsibility; (2) SSR behavior, which requires personally responsible persons; and (3) Sustainable leadership and sustainable leaders. Then, we present how to achieve the overall new well-being of a society.

\subsubsection{Sustainable Personal and Corporate and Societal Social Responsibility}

Business valuation is no longer measured solely in the amount of financial profit or in terms of sales of goods and services, because it is too expensive, once summarized. There 
are several contemporary concepts in which organizations have become legal entities, considered as individuals with direct social effects on the society surrounding them, especially the environment in which they operate.

Until now, the most important of these concepts is the concept of (corporate) social responsibility towards (local) society, the safety and health of its products, and its contribution to various social activities (ranging from the fight against poverty to pollution control, to playing a central role in the processes of sustainable development in its ongoing commitment to providing different services and goods that help attain an improved living standard and contribute to the environmental development, benefiting the community and paying attention to social responsibility towards the external environment and within the aforementioned organizations) [89]. The main three concepts of (sustainable) corporate social responsibility by ISO 26000 [133] are applied to all organizations and require governments and big organizations to be role models.

In a cultural and professional social circle, people earn results and rewards in moral forms. Interdisciplinary ecologically focused education is focused on the creation of spiritual and professional persons and a moral and professional social-ecological environment [99].

When SSR companies want to make decisions, they think about their impact on society and its environment. They then strike a balance between stakeholder needs and their own benefits. Carroll [134] already based social responsibility on the functioning of an organization for the benefit of society and defined it as corporate social responsibility, including economic, legal and ethical expectations. These different concepts can come from different values, attitudes, languages, religions or identities.

Even specific elements of social responsibility are conceived differently [135]. Definitions of CSR are unclear, except in ISO 26000 as a globally passed advisory standard [32,133]. Relationships between the concepts of corporate social responsibility and sustainability [25] and future trends [136] are also important.

The COVID-19 pandemic, e.g., has generated a global health, economic and social crisis. CSR strategies can be a useful and effective tool to face the global problems of the pandemic, limiting the social externalities derived from the effects of COVID-19 and the security measures that it requires [137]. This crisis also offers great opportunities for firms to actively engage in various CSR initiatives during the crisis, and potentially catalyze a new era of CSR development in the long run [138]. Researchers [139] have mentioned types of CRS actions that governments and organizations can implement in the COVID-19 pandemic and what their relative effectiveness is. "COVID-19 Pandemic is an important vector in people's behavioral change, which reflects on environmental sustainability and social responsibility" [140].

Public institutions can take responsibility for saving resources and encourage employees to perform their tasks to ensure transparency in procurement, decision-making and other similar procedures [141].

\subsubsection{SSR Behavior Requires Personally Responsible Persons}

Personal responsibility is defined as the «responsibility of each individual to accept responsibility for their thoughts, words, behavior, decisions, mistakes, well-being effort, and influence» [71].

If humans wish to be personally responsible, they must be also requisitely holistic and practice VCENH. Every human being is multilayered; he/she is partly connected to different levels, but is in synergy: (i) physical/biological/natural (body), (ii) spiritual (sympathy, perception, thinking and will-power), (iii) social/sociable (individual's relationships to others, interpersonal relations and social harmony-social integration, involvement in different life roles), (iv) spiritual (self-realization, for one's life purpose) and (v) economic (satisfying one's material needs, as a family member, co-worker and a wider community member), etc.; a human is identified by the relatively holistic pattern of lasting features that separate people from each other, while he/she may simultaneously be an expert with a stronger or weaker creative skill and will for interdisciplinary cooperation. An individual's 
requisite personal holism is based on the following dimensions: (i) physical/body balance, (ii) mental maturity, (iii) social integration, (iv) spiritual maturity, (v) economic stability, etc. Necessary and sufficient, i.e., requisite, personal holism is measured by defined dimensions, while progress is ensured by different techniques, and understanding of those has also been studied [40-42].

\subsubsection{Sustainable Leadership and Sustainable Leaders in 'Well-Being Society 6.0'}

For the implementation of the new 'Well-being Society 6.0', there are important leaders and their leadership styles. Some definitions of leadership are listed in Table 1.

Table 1. Definitions of leadership.

\begin{tabular}{|c|c|}
\hline & DEFINITION \\
\hline 1 & $\begin{array}{l}\text { "Leadership is the process of influencing others to understand and agree on what } \\
\text { needs to be done and how to do it, and the process of facilitating individual and } \\
\text { collective efforts to accomplish shared objectives" [142] }\end{array}$ \\
\hline 2 & $\begin{array}{l}\text { "Leadership is constituting a process of social influence that is enacted by } \\
\text { designated individuals who hold formal leadership roles in organizations" [143] }\end{array}$ \\
\hline 3 & $\begin{array}{l}\text { "Leadership is a relationship between those who aspire to lead and those who } \\
\text { choose to follow. It's the quality of relationship that matters most when we're } \\
\text { engaged in getting extraordinary things done" [144] }\end{array}$ \\
\hline 4 & $\begin{array}{l}\text { "Leadership is a process whereby an individual influences a group of individuals to } \\
\text { achieve a common goal" [145] }\end{array}$ \\
\hline 5 & $\begin{array}{l}\text { "Leadership involves the dynamic and influential relationship between leaders } \\
\text { (with or without positional authority) and groups of people" [146] }\end{array}$ \\
\hline
\end{tabular}

Speaking of leadership, there are some normative models of leadership theories. A normative model of leadership theory consists of explicit moral norms for analyzing leaders and leadership [147]. Such normative models are: Servant, Transformational, Authentic, Ethical, Responsible and Spiritual leadership [95].

After [148], a leader is someone who can craft a vision and inspire people to act collectively to make it happen, responding to whatever changes and challenges arise along the way. This definition of leader is in close connection with sustainability [149] and therefore also with the new 'Well-being Society 6.0' (as briefed here). Leadership characteristics applied within the context comprising the economic, social and environmental challenges facing the world and humankind's aspirations for a more sustainable future are important. Ref. [149] mentioned that the synthesized version of the model includes in the first place seven key characteristics of leadership for sustainability, including:

- Systemic understanding (in-depth, requisitely holistic interdisciplinary research and understanding of the processes of investment and resource development);

- Emotional intelligence (inspiring people to act through their hearts);

- Value orientation (presence of honest values that are reflected in the way leaders behave and interact with the world);

- Compelling vision (effectively presenting a compelling story of how their organizations will contribute to a better world);

- Inclusive style (the leader and followers work together to achieve certain outcomes);

- Innovative approach (thinking creatively and solving problems together, which includes designing products and services); and

- Long-term perspective (anticipating, planning, assessing and analyzing the mediumand long-term consequences of the organization's policy and activities, and taking into account the behavior towards them). 


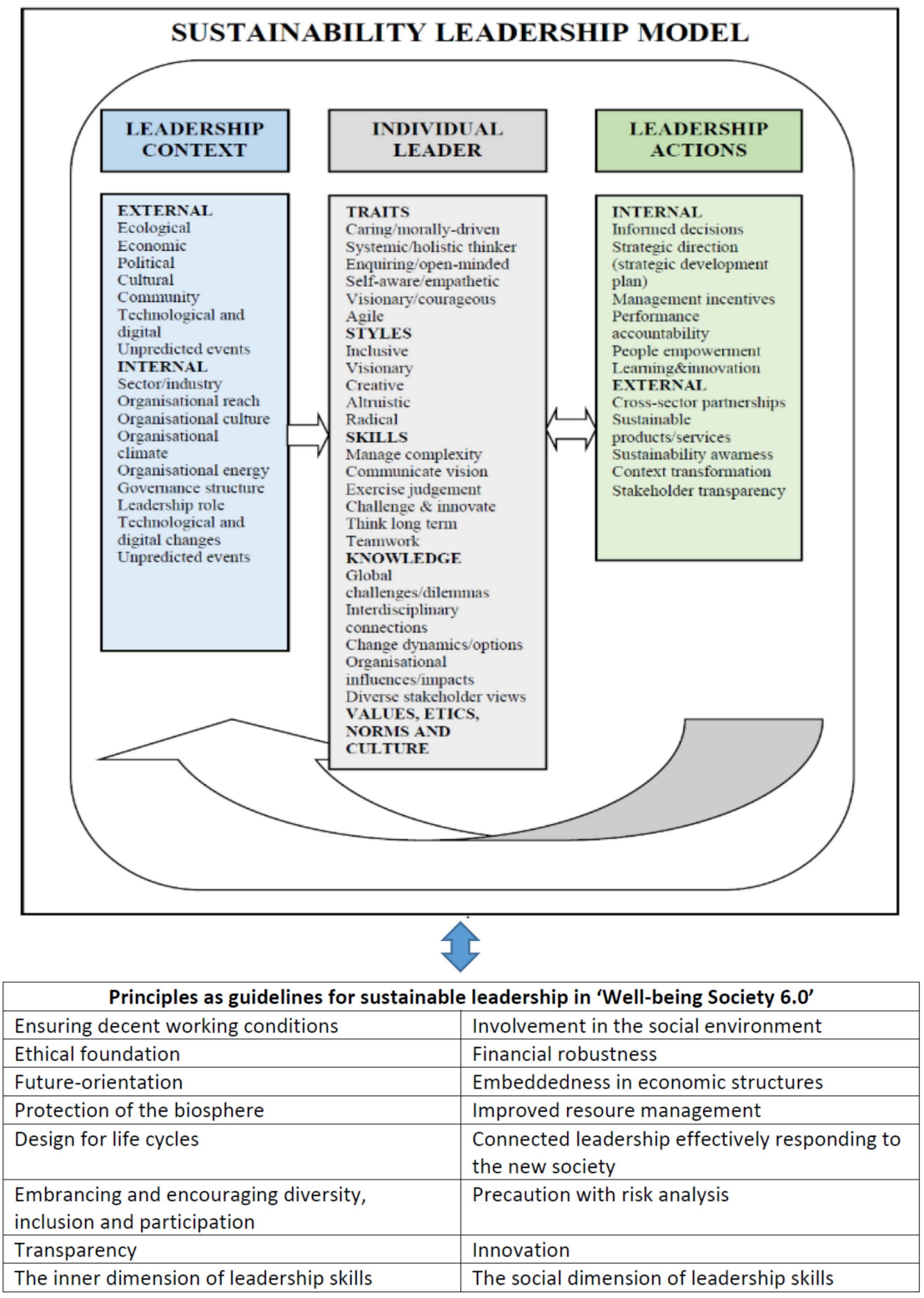

Figure 4. Upgraded Sustainability Leadership Model. Source: [148,150,151].

Based on the above statements, we upgraded the Cambridge theoretical model that has three main elements: context, personal characteristics and actions. Therefore, we present an Upgraded Sustainability Leadership Model in Figure 4. We consider it a component of the SSR society and 'Well-being Society 6.0'.

In Table 2, you can see that there are six very important principles as guidelines for sustainable leadership [70]. These principles help organizations deliver on the SDGs, including creating jobs, innovating new technologies, and better use of resources such as energy and water [150]. These principles and their connections to the SDGs are presented in Table 2. The principles enlisted for each of the dimensions present more than a checklist for compliance; they serve as a guideline for the management's general approach to leadership, provide individual orientation to managers and other employees, and enable them to compare practices with other organizations [70], and, to some extent, also communities and societies. 
Table 2. Principles as guidelines for sustainable leadership in 'Well-being Society 6.0'. Source: [70,150].

\begin{tabular}{|c|c|c|}
\hline Area & SDGs & Principles \\
\hline Social sustainability & $\begin{array}{c}\text { No Poverty (1) } \\
\text { Zero Hunger (2) } \\
\text { Good Wealth and Well-being (3) } \\
\text { Quality Education (4) } \\
\text { Gender Equality (5) } \\
\text { Reduced Inequalities (10) }\end{array}$ & $\begin{array}{l}\text { Ensuring decent working conditions; } \\
\text { Involvement in the social environment; } \\
\text { Ethical foundation }\end{array}$ \\
\hline Economic sustainability & $\begin{array}{c}\text { Clean Water and Sanitation (6) } \\
\text { Affordable and Clean Energy (7) } \\
\text { Decent Work and Economic Growth (8) } \\
\text { Industry, Innovation, and Infrastructure (9) } \\
\text { Sustainable Cities and Communities (11) }\end{array}$ & $\begin{array}{l}\text { Financial robustness; } \\
\text { Future-orientation; } \\
\text { Embeddedness in economic structures; }\end{array}$ \\
\hline Environmental sustainability & $\begin{array}{c}\text { Responsible Consumption and Production (12) } \\
\text { Climate Action (13) } \\
\text { Life Below Water (14) } \\
\text { Life on Land (15) }\end{array}$ & $\begin{array}{l}\text { Protection of the biosphere; Improved } \\
\text { resource management; } \\
\text { Design for life cycles }\end{array}$ \\
\hline Procedural sustainability & $\begin{array}{l}\text { Peace and Justice Strong Institutions (16) } \\
\text { Partnerships to achieve the Goal (17) }\end{array}$ & $\begin{array}{c}\text { Connected leadership effectively responding } \\
\text { to the complex world; } \\
\text { Embracing and encouraging diversity, } \\
\text { inclusion and participation; } \\
\text { Precaution with risk analysis; } \\
\text { Transparency; } \\
\text { Innovation }\end{array}$ \\
\hline \multirow[t]{2}{*}{ Personal sustainability } & & $\begin{array}{c}\text { The inner dimension of leadership skills: } \\
\text { Mindfulness } \\
\text { Continuous learning } \\
\text { Adaptability and flexibility } \\
\text { Sense of responsibility and ethics } \\
\text { Thinking in multiple perspectives }\end{array}$ \\
\hline & & $\begin{array}{c}\text { The social dimension of leadership skills: } \\
\text { Team building } \\
\text { Formulating vision } \\
\text { Building networks and facilitating trust } \\
\text { Understanding social settings }\end{array}$ \\
\hline
\end{tabular}

\subsubsection{How to Achieve the Overall New Well-Being Society 6.0}

Humans may use smart non-technological engineering as a combination of knowledge acquired through selected approaches to select optimal management functions and concepts for use in a given situation. See Figure 5.

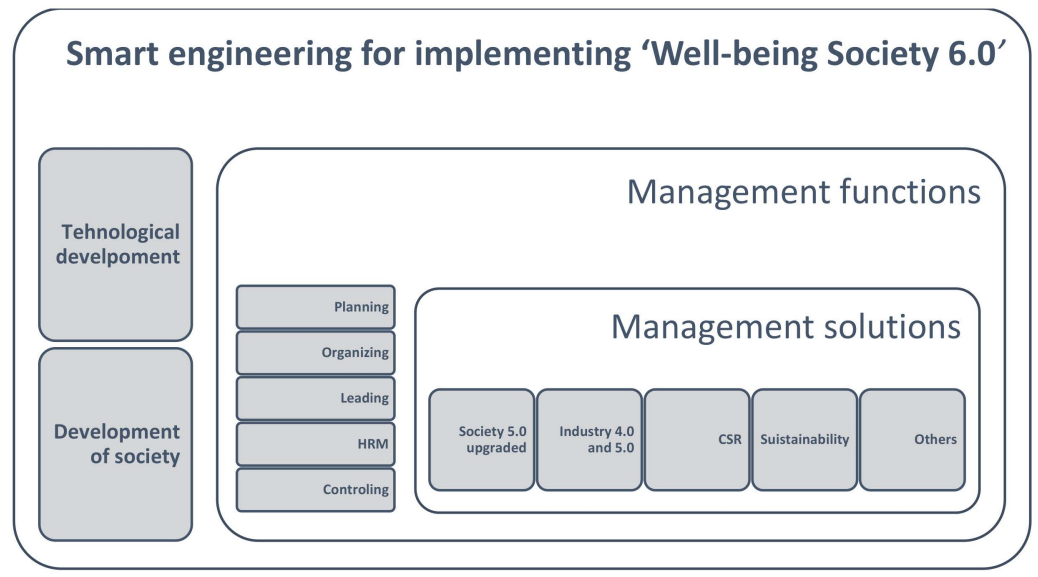

Figure 5. Smart non-technological engineering-how to achieve 'Well-being Society 6.0'. 


\subsubsection{Strategic Management at the Level of Society}

The new 'Well-being Society $6.0^{\prime}$ ' reaches beyond single individuals and organizations toward political options. The society's strategy or its development program is based on consolidating the views of the political options that make up the coalition and are the ones to sign the coalition agreement. The process of forming a coalition and drafting a contract is the foundation of a society's strategic development program and is part of shaping the strategy of a government. It is a planning decision that determines the basic ways to achieve the development goals of a society, which must be aimed at achieving overall well-being. In the context of this planned decision, the leaders of political parties must not forget to define the vision of the country they lead, nor to assess (opportunities and threats of) the environment and the state and thus society in terms of strengths and weaknesses. In essence, researchers help politicians with a comprehensive analysis of the given and new well-being of a society, as it is an effective and valuable tool, which:

- Provides the basis for the long-term success and development of the society,

- Provides a precise starting point on which the society can build a strategic approach to achieving prosperity for all stakeholders,

- Identifies areas of strength, power, danger and risk that enable or prevent rapid effective action,

- Provides insight into the means of improving well-being in many of the best companies,

- Offers cohesion with the latest management and governance standards.

Researchers/consultants present all the results of the analysis to clients briefly and concisely, and equip the results with practical and simple advice that can be easily incorporated into an organization's well-being strategy.

Professionally prepared and provided information on the state of well-being is the basis for defining measures for improvement. Therefore, this is the basis for setting the basic goals and policies to define and achieve a clever vision, from which the strategies, tactics, measures, projects and other activities for achieving the defined goals are derived.

Creating a strategy is the first phase of the strategic management process, followed by the strategy implementation phase, which is based on the enforcing and evaluation of the implementation of the strategy, where researchers can be an important pillar for decision makers. Once the management or government approves the strategy and approves the necessary resources for its implementation, an important phase of transferring the strategy into measurable key success indicators follows, with the help of which one will monitor the implementation of the strategy in various areas of business. Indicators must be related to material well-being (income and wealth, employment), social well-being (education, upbringing, health, security, social cohesion, political voice and governance, life satisfaction) and environmental well-being (natural environment).

This means that researchers/consultants will set up a precise control system, which will cover the following dimensions of society's well-being:

- Income and wealth;

- Work activities;

- Housing conditions;

- Education and upbringing;

- Health;

- Security;

- Social cohesion;

- Political voice and governance;

- Life satisfaction, and;

- Natural environment.

\section{Conclusions}

After reviewing the literature on the Society 5.0 concept, we can conclude that it influences a wide range of areas with which we as individuals are connected on a daily 
basis. The perception of Society 6.0 may seem a bit idealistic, but at the same time we believe that the goals of Society 6.0 are definitely something humans should strive for as a modern society, seeking a way out from the current global socio-economic crisis (beyond growth as the common denominator). Society 6.0 also represents a great (potential) innovation of the characteristics of society, as society in this case represents humanity. Namely, the goal is to smooth out all disagreements and convince humanity that every individual follows the goals of Society 6.0, the essence of which is the SSR society [5].

It will take a lot of effort for Society 5.0, the new 'Well-being Society 6.0' and the SSR society to become a reality by achieving the set goals, backed by convincing all of humanity that people need a way out from the current neoliberal global crisis and the threat of global self-destruction. Therefore, humans must pursue the same goals and put aside differences that do not lead to synergies but rather to danger, which is very challenging. Yet, society has the ability to change, even to innovate the usual narrow and short-term selfishness; therefore, it is an innovation of values, which humanity has defined more at the level of global charters of social responsibility than at the level of personal practice. Customers, though, are entitled to be selfish, including their right to require suppliers to offer total quality, including individual, corporate and societal sustainable social responsibility [39]; every person, every organization, every government and every society is both a customer (of what they need and others supply) and a supplier (of what others need).

The sources in question overlook the realization that in the historical development of humankind, the basis of competitiveness has changed greatly from the ownership of natural resources through investment and innovation to the abundance/affluence of the most innovative people and societies; in doing so, the experience of affluence destroying the need and will to work hard is important, making free time favored to additional owning, resulting in a crisis of affluence causing hyper-production (more in $[5,28]$ ). ICT can support overworking, which is mostly self-serving, as it does not allow for a quality work-life balance, or shorter working hours (some successful cases of a four-day working week were reported by the public media in fall 2019, but they did not mention the need to have meaningful leisure time). Additionally, these sources do not deal with the issue of the ownership of knowledge and capital in the same hands/heads in cooperatives, workers' shareholding, the incorporation of social responsibility into the strategy of companies and states and other bodies of society from local to global levels or other aspects and motivating factors. See, for example, the following sources [5,28,30,31,33,34,43].

Today, the progress and development of technology have a lot to offer. Thus, it is important that Society 6.0 involves collaboration between technology and individuals and not merely the replacement of hard-working individuals with machines. Many are already aware that the development of technology also means the development and education of staff in organizations. Fast-paced development demands a greater ability and will to learn; this will not be easy to attain with everybody.

The will to define selfishness remains essential, so that humans do not involve only themselves but also take the broader and longer-term consequences of their actions into account. The selfishness of customers, who demand excellent satisfaction of their needs for any products and/or services, can encourage the development of social responsibility as a basis for it [152]. Survival is at stake, let us stress it again!

The system/regulation of education is also very important, even before entering the labor market and later in our lives. It is supposed to teach humans cooperative, innovative and critical thinking and instill this into the prevailing VCENH, but in reality, it is very different- the ability to learn by heart, without critical and creative thinking, or even innovative understanding of the content, is appreciated (a good example is the 'marathon of positive psychology' in Slovenia). Individuals who are the product of such outdated education and upbringing feel lost when they enter the labor market because they did not acquire the right knowledge and VCENH through education, which would serve as the basis for understanding and comprehending the management of the world around them. Society 5.0 and 6.0 will also mean a huge need for innovation for upbringing, education, 
and development, which, due to the change in technology (but also regardless of it), will basically never end. Even more demanding might be the new well-being society.

In addition to the development of technology, society also strives for cooperation between individuals, companies or other organizations and the environment, as they exist in interdependence and synergy. All three are therefore supposed to be balanced. Development should aim to find solutions that relieve the environment and improve life both in water and on land. At a time when humans are increasingly aware of what is happening and of drastic bad changes in the environment, this seems like a very welcome and sensible step - to work for the benefit of the environment and thus humanity, as we humans live in this environment. The importance of the individual's contact with nature is emphasized, as this is supposed to be one of the ways to achieve the satisfaction of individuals, which is one of the central goals of Society 5.0, and even more so in an SSR society, as it puts the individual and his/her well-being at the forefront.

Let us briefly remind you of a crucial issue that seems to be left aside in Industry 4.0, Industry 5.0 and Society 5.0 documents: peace and the weapons industry. We mentioned security, including peace, as a crucial component of an SSR society. For millennia, people have known the principle guideline of peace: 'Si vis pacem, para bellum', meaning: 'If you want peace, prepare for war'. However, history tells us that this guideline has never worked. An SSR society might be hard to attain, but peace is worth the effort. War serves only the weapons industry, located mostly in member countries of the UN Security Council, and mostly destroys life in other countries. This fact makes SSR societies urgent, including Society 5.0 and the new 'Well-being Society 6.0'.

Obstacles against this innovation of the currently prevailing neoliberalism include the profits of monopolistic global companies covering their untouchable reigning power position in the global economy; no government has been able to control them over the recent nearly seven decades [152]. In 2020-2021, the medical, state and business worlds were shocked by the new coronavirus crisis. We cannot discuss the medical aspect of this crisis, but the global economic consequences on the basis of data were investigated by authors of $[130,153]$. The European Union is collecting a huge amount of money for EU member states to help their economies recover, mostly by infrastructure building and renewal projects. An even more directly visible link to the Keynes state capitalism is visible in the USA: President Joe Biden is being compared with President D. F. Roosevelt, who solved the crisis of the 'big depression' of the 1930s by huge public works. Thus far, no global economic institution has protested. More ethics of a sustainable socially responsible society and more interdependence and requisite holism are entering the global economy than ever since after the 1950s, when the application of Keynesian economics was gradually replaced by neoliberal power of corporations, which is now coming back. This may become a crucial economic consequence of the new coronavirus crisis. It would be necessary anyway because the crisis of neoliberalism that became visible and recognized in 2008 led to the passing of ISO 26000 in 2010; the concept of the SSR society started being installed for humanity to overcome its danger of global self-destruction by climate change and the 3rd World War. The crucial first steps are here: strong official global documents and promises, accepted obligations to diminish and mitigate the warming of the planet, and non-profit public good investment under the control of the government and government-controlled banks and funds.

'Well-being Society 6.0' is not based solely on material goods and the enjoyment of these, but on thoughtfully exploited opportunities and givens, an unspoiled environment, satisfied and happy people who live according to their mission and the gifts given to achieve this, etc. What is important is the most comprehensive quality of life, which is the foundation of a modern welfare society that is socially responsible.

Because no similar concept is offered in the available literature, we developed an important research question and we answered it here in the limited space given. 


\subsection{Practical Implications}

Neoliberal society forgets about humans, nature and their givens, and their interconnectedness. It forgets the limits of expansive development and the need for sustainable and long-term existence, and it does not consider the limited and heavily overloaded natural capabilities and possibilities of planet Earth. As a society, we are constantly driving in the overtaking lane. Therefore, we struggle to establish prosperity on all levels; at the level of the individual, the organization, and society with 'Well-being Society 6.0'.

'Well-being Society 6.0 ' takes into account interconnections between all relevant stakeholders, and this can prepare individual countries for the social and economic impacts involved in the current trend of digitization and automation.

The concept of 'Well-being Society 6.0' upgrades Industry 4.0, Industry 5.0 and Society 5.0. It is based on smart non-technological engineering. Smart non-technological engineering is a combination of values, knowledge, experiences, approaches, methods and solutions obtained through selected scientific and professional knowledge and non-technological innovations, which also use technological ones to be as comprehensive as possible in thinking and acting. This means that, based on values, knowledge and experience, we first define the key pillars of well-being, such as, e.g., professionalism, cooperation, management, social responsibility, well-being, digitalization, VCENH of personal and social responsibility and others. Then, for each pillar of prosperity, we intertwine the functions of management, classical and modern management solutions and tools of prosperity, such as training, education, workshops, events, counseling and coaching.

'Well-being Society 6.0' is the basis for the next step of societal development (which will necessarily be developed due to the COVID-19 pandemic).

\subsection{Opportunities for Further Research}

Further studies should focus on the following challenges:

- The fundamental research challenge is to discover and model the conditions for the formation of a sustainable socially responsible society called 'Well-being Society 6.0' through the interdisciplinary application of political science, sociology, law and the social responsibility governance theory; their common denominator is unacceptable social differences on both global and local levels.

- The political science challenge connected with a key social or political problem: how are the social wealth and political power that are created transferred from capital to workers and citizens in an SSR society.

- The sociological challenge of reducing income, wealth and other types of inequality and introducing forms of co-ownership and participation must be seen as a means for increasing social cohesion, which will be vital to bring about the democratic change of neoliberalism as well as people's behavioral patterns.

- The legal challenge is how to improve the legal frameworks for economic democracy, the social economy and corporate social responsibility by restructuring the existing relations between owners and workers, creating new corporate structures, sustainable human resource management and a new management style; the challenge is to gradually overcome income inequalities and to establish a new balance of profit/ownership distribution between owners and workers in a greater number of companies.

- The challenges of governance theory regarding SSR societies and other challenges.

\subsection{Research Limitations}

The research topic has been researched to the greatest extent possible, with qualitative analysis in desk and field research. A quantitative methodological approach will follow later.

Author Contributions: All authors participated in each chapter. All authors have read and agreed to the published version of the manuscript.

Funding: This research received no external funding. 
Institutional Review Board Statement: Not applicable.

Informed Consent Statement: Not applicable.

Data Availability Statement: Not applicable.

Acknowledgments: Research program from Slovenian Research Agency P5-0027: Prilagajanje slovenskega gospodarstva in razvojna identiteta Slovenije v EU.

Conflicts of Interest: The authors declare no conflict of interest.

\section{References}

1. Shen, J.; Benson, J. When CSR Is a Social Norm. How Socially Responsible Human Resource Management Affects Employee Work Behavior. J. Manag. 2016, 42, 1723-1746.

2. Kassin, S.; Fein, S.; Markus, H. Social Psychology; Cengage Learning: Belmont, CA, USA, 2017.

3. Šarotar Žižek, S.; Mulej, M. Pametna Proizvodnja Smart Production—Pametna Proizvodnja-Managementski Vidik in Vidik Zaposlenih; Pearson: Maribor, Slovenia; London, UK, 2019.

4. $\quad$ Šarotar Žižek, S.; Mulej, M.; Veingerl Čič, Ž.; Bobek, S.; Šebjan, U.; Tominc, P.; Frešer, B.; Kapun, S.; Sternad Zabukovšek, S.; Zabukovšek, U. Družbeno Odgovorna Uporaba IKT, (Zbirka Sodobni Izzivi Managementa Človeških Virov, Knj. 4); IRDO-Inštitut za Razvoj Družbene Odgovornosti: Maribor, Slovenia, 2018.

5. Mueller, B.; Eggers, F.; Brandimarte, L.; Diefenbach, S.; Kroschke, M.; Wirtz, J. Corporate digital responsibility. J. Bus. Res. 2021, 122, 875-888.

6. Mulej, M.; Merhar, V.; Žakelj, V.; Hrast, A.; Toplak, L.; Slapnik, T.; Ambrožič, B. Uvod v Politično 5 Ekonomijo Družbeno Odgovorne Družbe; IRDO Inštitut za Razvoj Družbene Odgovornosti Maribor in Kulturni center Maribor: Maribor, Slovenia, 2019.

7. Harayama, Y. Society 5.0: Aiming for a New Human-Centered Society. Japan's Science and Technology Policies for Addressing Global Social Challenges. Interviewed by Mayumi Fukuyama. Hitachi Rev. 2017, 66, 8-13.

8. Little, W. Introduction to Sociology, 2nd ed; BCcampus: Victoria, BC, USA, 2016; Available online: https://opentextbc.ca/ introductiontosociology2ndedition/ (accessed on 25 February 2021).

9. Fukuyama, M. Society 5.0: Aiming for a New Human-Centered Society. Jpn. Spotlight 2018, 1, 47-50.

10. Rego, A.; Cunha, M.P.; Polonia, D. Corporate Sustainability: A View from the Top. J. Bus. Ethics 2017, 143, 133-157. [CrossRef]

11. Japan Business Federation (Keidanren). Toward Realization of the New Economy and Society. Reform of the Economy and Society by the Deepening of "Society 5.0"; Keidanren: Tokyo, Japan, 2016.

12. Japan Business Federation (Keidanren). Society 5.0 for SDGs; Keidanren: Tokyo, Japan, 2019.

13. Narvaez Rojas, C.; Alomia Peñafiel, G.A.; Loaiza Buitrago, D.F.; Tavera Romero, C.A. Society 5.0: A Japanese Concept for a Superintelligent Society. Sustainability 2021, 13, 6567. [CrossRef]

14. Nakanishi, H. Modern Society Has Reached Its Limits— "Society 5.0" Will Liberate Us; World Economic Forum: Davos, Switzerland, 11 January 2019.

15. Higashihara, T. A Search for Unicorns and the Building of "Society 5.0"; World Economic Forum: Davos, Switzerland, 2018.

16. Etzioni, A. The Common Good; Polity Press: Oxford, UK, 2014.

17. Sandel, M. The Tyranny of Merit; Penguin Books: London, UK, 2020.

18. Krugman, P. Arguing with the Zombies: Economics, Politics, and the Fight for a Better Future; W. W. Norton \& Co.: New York, NY, USA, 2020

19. Stiglitz, J. The Price of Inequality; Penguin Books Ltd.: London, UK, 2015.

20. Piketty, T. Capital and Ideology; Harvard University Press: Cambridge, MA, USA, 2020.

21. Chavez-Avila, R.; Gallego-Bono, J.R. Transformative Policies for the Social and Solidarity Economy: The New Generation of Public Policies Fostering the Social Economy in Order to Achieve Sustainable Development Goals. The European and Spanish Cases. Sustainability 2020, 12, 4059. [CrossRef]

22. Felber, C. Change Everything: Creating an Economy for the Common Good; Zed Books: London, UK, 2019.

23. Felber, C.; Hagelberg, G. A Workable, Transformative, Ethics-Based Alternative, 1st ed.; Routledge: London, UK, 2020.

24. Ollé-Espluga, L.; Muckenhuber, J.; Hadler, M. Job quality in Economy for the Common Good firms in Austria and Germany. CIRIEC-España, Revista de Economía Pública, Social y Cooperativa 2020, 99, 177-202. [CrossRef]

25. Tirole, J. Economics for Common Good; Princeton Universty Press: Princenton, UK; Oxford, UK, 2016.

26. Felber, C.; Campos, V.; Sanchis, J.R. The common good balance sheet, an adequate tool to capture non-financials? Sustainability 2019, 11, 3791. [CrossRef]

27. Campos, V.; Sanchis, J.R.; Ejarque, A. Social entrepreneurship and Economy for the Common Good: Study of their relationship through a bibliometric analysis. Int. J. Entrep. Innov. 2020, 21, 156-167.

28. Council for Science, Technology and innovation (SCTI). Society 5.0; Ministry of Sciences and Technology: Tokyo, Japan, 2019.

29. Hope, K.R., Sr. Peace, justice and inclusive institutions: overcoming challenges to the implementation of Sustainable Development Goal 16. Global Change Peace Security 2020, 32, 57-77. [CrossRef]

30. Windsor, D. Corporate Social Responsibility: Three Key Approaches. J. Manag. Stud. 2006, 43, $93-114$.

31. Heck, S.; Rogers, M. Are you ready for the resource revolution? Mckinsey Q. 2014, 2, 32-45. 
32. Crifo, P.; Forget, V. The economics of corporate social responsibility: A firm-level perspective survey. J. Econ. Surv. 2015, 29, 112-130. [CrossRef]

33. Ferreira, C.M.; Serpa, S. Society 5.0 and Social Development: Contributions to a Discussion. Manag. Organ. Stud. 2018, 5, 26-31.

34. Iwano, K.; Kimura, Y.; Takashima, Y.; Bannai, S.; Yamada, N. (Eds.) Future Services E Societal Systems in Society 5.0; Center for Research and Development Strategy, Japan Science and Technology Agency: Tokyo, Japan, 2017.

35. Midin, M.; Joseph, C.; Mohamed, N. Promoting societal governance: Stakeholders' engagement disclosure on Malaysian local authorities' websites. J. Clean. Prod. 2017, 142, 1672-1683. [CrossRef]

36. Camerino, O.; Valero-Valenzuela, A.; Prat, Q.; Manzano Sánchez, D.; Castañer, M. Optimizing Education: A Mixed Methods Approach Oriented to Teaching Personal and Social Responsibility (TPSR). Front. Psychol. 2019. [CrossRef]

37. Galvão, A.; Mendes, L.; Marques, C.; Mascarenhas, C. Factors Influencing Students' Corporate Social Responsibility Orientation in Higher Education. J. Clean. Prod. 2019, 215, 290-304. [CrossRef]

38. Mulej, M. Dialektična in Druge Mehkosistemske Teorije: (Podlage za Celovitost in Uspeh Managementa); Ekonomsko-Poslovna Fakulteta: Maribor, Slovenia, 2000.

39. EC/EU. A Renewed EU Strategy 2011-2014 for Corporate Social Responsibility; European Commission: Brussels, Belgium, 2011.

40. Pauyuoliene, J.; Mauriciene, I. Implementation of Social Responsibility in Public Institution. Soc. Tyrim. Soc. Res. 2013, 4, 141-151.

41. Šarotar Žižek, S. Vpliv Psihičnega Dobrega Počutja na Temelju Zadostne in Potrebne Osebne Celovitosti Zaposlenega na Uspešnost Organizacije. Ph.D. Thesis, University of Maribor, Maribor, Slovenia, November 2012.

42. Šarotar Žižek, S. (Ed.) Zagotavljanje Zadostne in Potrebne Osebne Celovitosti Človeka; Zbirka Well-Being; Inštutut za Razvoj Družbene Odgovornosti (IRDO): Maribor, Slovenia, 2015.

43. Altman, D.; Flavin, P.; Radcliff, B. Democratic Institutions and Subjective Well-Being. Polit. Stud. 2017, 65, 1-20. [CrossRef]

44. Potočnik, A. Viabilna Regija-Rezultat Inoviranja z Dialektično Teorijo Sistemov in Kibernetiko Poslovnih Sistemov. Ph.D. Thesis, UM EPF, Maribor, Slovenia, 2016.

45. Mlakar, T.; Mulej, M. On the concept of the "control systems theory" as a new model of systemic consideration. Kybernetes 2008, 37, 215-225. [CrossRef]

46. Mulej, M.; Merhar, V.; Žakelj, V. (Eds.) Družbeno-Ekonomski Okvir in Osebne Lastnosti Družbeno Odgovornih. Trilogija Nehajte Sovražiti Svoje Otroke in Vnuke, Prva Knjiga; Zbirka Frontier Books; IRDO Inštitut za Razvoj Družbene Odgovornosti Maribor in Kulturni Center Maribor: Maribor, Slovenia, 2016.

47. Abad-Segura, E.; Cortés-García, F.J.; Belmonte-Ureña, L.J. The Sustainable Approach to Corporate Social Responsibility: A Global Analysis and Future Trends. Sustainability 2019, 11, 5382. [CrossRef]

48. Maresova, P.; Soukal, I.; Svobodova, L.; Hedvicakova, M.; Javanmardi, E.; Selamat, A.; Krejcar, O. Consequences of Industry 4.0 in Business and Economics. Economies 2018, 6, 46. [CrossRef]

49. Ahmad, S.; Miskon, S.; Alabdan, R.; Tlili, I. Towards Sustainable Textile and Apparel Industry: Exploring the Role of Business Intelligence Systems in the Era of Industry 4.0. Sustainability 2020, 12, 2632. [CrossRef]

50. Parschau, C.; Hauge, J. Is automation stealing manufacturing jobs? Evidence from South Africa's apparel industry. Geoforum 2020, 115, 120-131. [CrossRef]

51. Mckinsey Global Institute. A Future that Works: Automation, Employment, and Productivity; McKinsey and Company: San Francisco, CA, USA, 2017.

52. Turnea, E.-S.; Neștian, Ș.A.; Tiță, S.M.; Vodă, A.I.; Guță, A.L. Dismissals and Temporary Leaves in Romanian Companies in the Context of Low Demand and Cash Flow Problems during the COVID-19 Economic Lockdown. Sustainability 2020, 12, 8850. [CrossRef]

53. Zengin, Y.; Naktiyok, S.; Kaygın, E.; Kavak, O.; Topçuoğlu, E. An Investigation upon Industry 4.0 and Society 5.0 within the Context of Sustainable Development Goals. Sustainability 2021, 13, 2682. [CrossRef]

54. Salimova, T.; Guskova, N.; Krakovskaya, I.; Sirota, E. From industry 4.0 to Society 5.0: Challenges for sustainable competitiveness of Russian industry. Iop Conf. Ser. Mater. Sci. Eng. 2019, 497, 1-7. [CrossRef]

55. Lee, J.; Bagheri, B.; Kao, H.A. A Cyber-Physical Systems architecture for Industry 4.0-based manufacturing systems. Manuf. Lett. 2015, 3, 18-23. [CrossRef]

56. Takahashi, T. Behavioral Economics of Addiction in the Age of a Super Smart Society: Society 5.0. Oukan J. Transdiscipl. Fed. Sci. Technol. 2018, 12, 119-122.

57. Ban, P. Gospodarska Rast in Koncept Sreče v Tržnih Družbah. Ph.D. Thesis, Univerza v Mariboru, Ekonomsko-Poslovna Fakulteta, Maribor, Slovenia, 2017.

58. Franca, I. Statistična Analiza Blaginje v Sloveniji in Primerjava z Izbranimi Državami. Ph.D. Thesis, Univerza v Ljubljani, Fakulteta za Upravo, Ljubljana, Slovenia, September 2016.

59. Kovačič, N. Primerjava Ravni Blaginje v Sloveniji v Primerjavi z Drugimi Državami Evropske Unije. Ph.D. Thesis, Univerza na Primorske, Fakulteta za Management, Koper, Slovenia, 2018.

60. Nikolić, G. Je li industrija 5.0 odgovor na industriju 4.0 ili njen nastavak? Polytech. Des. 2018, 6, 1-8.

61. Stanojević, A. Oblikovanje Integriranega Modela Blaginje. Master's Thesis, Univerza v Ljubljani, Fakulteta za Upravo, Ljubljana, Slovenia, September 2016.

62. Roblek, V.; Meško, M.; Krapež, A. A complex View of Industry 4.0. Sage Open 2016, 6, 1-11.

63. Lasi, H.; Fettke, P.; Kemper, H.-G.; Feld, T.; Hoffmann, M. Industry 4.0. Bus. Inf. Syst. Eng. 2014, 6, 239-242. [CrossRef] 
64. Hennies, M.O.E.; Raudjärv, M. Industry 4.0. Introductory thoughts on the current situation. Est. Discuss. Econ. Policy 2015, 23, 19-23. [CrossRef]

65. Mosconi, F. The New European Industrial Policy: Global Competitiveness and the Manufacturing Renaissance; Routledge: London, UK, 2015.

66. Shiroishi, Y.; Uchiyama, K.; Suzuki, N. Better Actions for Society 5.0: Using AI for Evidence-Based Policy Making That Keeps Humans in the Loop. Computer 2019, 52, 73-78. [CrossRef]

67. Minton, E.; Khale, L. Belief Systems, Religion, and Behavioral Economics; Business Expert Press: New York, NY, USA, 2014.

68. Wang, H.; Tong, L.; Takeuchi, R.; George, G. Corporate Social Responsibility: An Overview and New Research Directions: Thematic Issue on Corporate Social Responsibility. Acad. Manag. J. 2016, 59, 534-544. [CrossRef]

69. Mulej, M.; Dyck, R. Social Responsibility_Range of Perspectives Per Topics and Countries (Social Responsibility beyond Neoliberalism and Charity, Vol. 4); Bentham: London, UK, 2015.

70. McWilliams, A.; Siegel, D. Corporate social responsibility and financial performance: Correlation or misspecification? Strateg. Manag. J. 2000, 21, 603-609. [CrossRef]

71. Mrak Hendrickson, S. Personal responsibility European guidelines for sustainable leadership. In Social Responsibility and Current Challenges 2020: Personal and Social Responsibility for Sustainable Future. In Proceedings of the 15th IRDO International Science and Business Conference Social Responsibility and Current Challenges 2020: Personal and Social Responsibility for Sustainable Future, Maribor, Slovenia, 4-5 June 2020.

72. Rauter, M. Social responsibility begins with personal responsibility. In Social Responsibility and Current Challenges 2020: Personal and Social Responsibility for Sustainable Future. In Proceedings of the 15th IRDO International Science and Business Conference Social Responsibility and Current Challenges 2020: Personal and Social Responsibility for Sustainable Future, Maribor, Slovenia, 4-5 June 2020.

73. Dombrowski, U.; Richter, T.; Krenkel, P. Interdependencies of Industrie 4.0 \& Lean Production Systems: A Use Cases Analysis. Procedia Manuf. 2017, 11, 1061-1068.

74. Ning, H.; Liu, H. Cyber-physical-social-thinking space based science and technology framework for the Internet of things. Sci. China Inf. Sci. 2015, 58, 1-19. [CrossRef]

75. Cooper, J.; James, A. Challenges for database management in the Internet of things. Iete Tech. Rev. 2009, 26, 320-329. [CrossRef]

76. Almada-Lobo, F. The Industry 4.0 revolution and the future of manufacturing execution systems (MES). J. Innov. Manag. 2016, 3, 16-21. [CrossRef]

77. Schlechtendahl, J.; Keinert, M.; Kretschmer, F.; Lechler, A.; Verl, A. Making existing production systems Industry 4.0-ready. Prod. Eng. 2015, 9, 143-148. [CrossRef]

78. Roblek, V.; Meško, M.; Pejić Bach, M.; Thorpe, O.; Šprajc, P. The Interaction between Internet, Sustainable Development, and Emergence of Society 5.0. Data 2020, 5, 80. [CrossRef]

79. Mi’skiewicz, R.; Wolniak, R. Practical Application of the Industry 4.0 Concept in a Steel Company. Sustainability 2020, $12,5776$. [CrossRef]

80. Kagermann, H.; Wahlster, W.; Helbig, J. Recommendations for Implementing the Strategic Initiative Industrie 4.0, Securing the Future of German Manufacturing Industry. In Final Report of the Industrie 4.0 Working Group; National Academy of Science and Engineering: Frankfurt am Main, Germany, 2013.

81. Neumann, W.; Winkelhaus, S.; Grosse, E.H.; Glock, C.H. Industry 4.0 and the human factor-A systems framework and analysis methodology for successful development. Int. J. Prod. Econ. 2021, 233, 107992. [CrossRef]

82. Ejsmont, K. The Impact of Industry 4.0 on Employees-Insights from Australia. Sustainability 2021, 13, 3095. [CrossRef]

83. Salimova, T.; Vukovic, N.; Gruskova, N.; Krakovskaya, I. Industry 4.0 and Society 5.0: Challenges and Opportunities, The Case Study of Russia. Smart Green City 2021, 17, 4.

84. Štrukelj, T. Responsible governance and strategies, competitiveness and sustainable socially responsible society. In Bases for a Sustainable Socially Responsible Society, Trilogy, Book 2: Some Selected Societal, Governmental and Organizational Viewpoints, Coauthored Monograph; Mulej, M., Hrast, A., Štrukelj, T., Šarotar Žižek, S., Eds.; Springer: Berlin, Germany, 2021.

85. Prasetyo, Y.A.; Arman, A.A. Group Management System Design for Supporting Society 5.0 in Smart Society Platform. In Proceedings of the International Conference on Information Technology Systems and Innovation (ICITSI), Bandung, Indonesia, 23-24 October 2017.

86. Mulej, M.; Božičnik, S.; Čančer, V.; Hrast, A.; Jurše, K.; Kajzer, Š.; Knez-Riedl, J.; Jere Lazanski, T.; Mlakar, T.; Mulej, N. Dialectical Systems Thinking and the Law of Requisite Holism Concerning Innovation; Emergent Publications: Litchfield Park, AZ, USA, 2013.

87. Medina-Borja, A. Smart Human-Centered Service Systems of the Future. In Future Services \& Societal Systems in Society 5.0; Iwano, K., Kimura, Y., Takashima, Y., Bannai, S., Yamada, N., Eds.; Center for Research and Development Strategy, Japan Science and Technology Agency: Tokyo, Japan, 2017; pp. 235-239.

88. Demir, A.K. Cicibaş, Industry 5.0 and a Critique of Industry 4.0. In Proceedings of the 4th International Management Information Systems Conference "Industry 4.0", İstanbul University, İstanbul, Turkey, 17-20 October 2017.

89. Javaid, M.; Haleem, A.; Singh, R.P.; Haq, M.I.U.; Raina, A.; Suman, R. Industry 5.0: Potential applications in covid-19. J. Ind. Integr. Manag. 2020, 5, 4. [CrossRef]

90. Rada, M. Industry 5.0—From Virtual to Physical. 2015. Available online: https://www.linkedin.com/pulse/industry-50-fromvirtual-physical-michael-rada/?trk=mp-reader-card (accessed on 10 December 2020). 
91. Heifetz, R.A.; Linsky, M. Leadership on the Line: Staying Alive through the Dangers of Leading; Harvard Business School Press: Boston, MA, USA, 2002.

92. Nikolić, G. Budućnost robota je u suradnji (kolaboraciji) s čovjekom-Partner kobot. Open. Info. Trend. 2017, $205,58-63$.

93. Ruttan, V. Induced Innovation, Evolutionary Theory and Path Dependence: Sources of Technical Change. Econ. J. 1997, 107, 1520-1529. [CrossRef]

94. Government of Japan. The 5th Science and Technology Basic Plan. Provisional Translation. 22 January 2016. Available online: https:/ / www8.cao.go.jp/cstp/english/basic/5thbasicplan.pdf (accessed on 25 March 2019).

95. Reave, L. Spiritual values and practices related to leadership effectiveness. Leadersh. Q. 2005, 16, 655-687. [CrossRef]

96. United Nation (UN). Transforming Our World: The 2030 Agenda for Sustainable Development, Transforming Our World: The 2030 Agenda for Sustainable Development Sustainable Development. Un.org A/RES/70/1. 2015. Available online: https://sdgs. un.org/sites/default/files/publications /21252030\%20Agenda\%20for\%20Sustainable\%20Development\%20web.pdf (accessed on 10 December 2020).

97. Potocan, V.; Mulej, M.; Nedelko, Z. Society 5.0: Balancing of Industry 4.0, economic advancement and social problems. Kybernetes 2020. [CrossRef]

98. Savaget, P.; Geissdoerfer, M.; Kharrazi, A.; Evans, S. The theoretical foundations of sociotechnical systems change for sustainability: A systematic literature review. J. Clean. Prod. 2019, 206, 878-892. [CrossRef]

99. ISO 2010: ISO 26000. Available online: http://www.iso.org/iso/discovering_iso_26000.pdf (accessed on 10 December 2020).

100. Bryndin, E. System Synergetic Formation of Society 5.0 for Development of Vital Spaces on Basis of Ecological Economic and Social Programs. Ann. Ecol. Environ. Sci. 2018, 1, 13-19.

101. Shiroishi, Y.; Uchiyama, K.; Suzuki, N. Society 5.0: For Human Security and Well-being. Computer 2018, 51, 91-95. [CrossRef]

102. Gladden, M.E. Who Will Be the Members of Society 5.0? Towards an Anthropology of Technologically Posthumanized Future Societies. Soc. Sci. 2019, 8, 148. [CrossRef]

103. Onday, O. Japan's Society 5.0: Going Beyond Industry 4.0. Bus. Econ. J. 2019, 10, 1-6.

104. Miller, R. (Ed.) Personalising Education. Organisation for Economic Co-Operation and Development; Taylor \& Francis e-Library: Paris, France, 2006.

105. Bryndin, E.G. Establishing of Harmonic Civil Society as a Social-Economic Formation of Stable Development and Wellbeing. In Proceedings of the III International Scientific Symposium on Lifelong Wellbeing in the World, Trento, Italy, 18-22 May 2015 ; 2017.

106. Bryndin, E.G. Solution of Problems of Resources, Ecology, Health and Poverty. J. Int. Sci. Res. 2013, 5, 86-89.

107. El-Mallah, R.K.E.-D.; Aref, A.A.e.H.; Sherif, S. The role of social responsibility in protecting the environment-A case of the petrochemical companies in Alexandria Governorate. Rev. Econ. Polit. Sci. 2019. ahead-of-print. [CrossRef]

108. Bryndin, E.G. Transition to Health Saving Up Innovative Economy. J. Int. Sci. Res. 2013, 5, 65-67.

109. Bryndin, E. Economic Aspect of Global Wellbeing. J. Eur. Proc. Soc. Behav. Sci. 2016, VII, 14-21.

110. Gorecky, D.; Schmitt, M.; Loskyll, M.; Zühlke, D. Human-Machine-Interaction in the Industry 4.0 Era. In Proceedings of the 12th IEEE International Conference on Industrial Informatics (INDIN), Porto Alegre, Brazil, 27-30 July 2014; pp. $289-294$.

111. Kang, J. Change: From Industry 4.0 to Society 5.0-Taking the Comparison of Related Development Strategies Between Germany and Japan as an Example. In Proceedings of the 4th International Conference on Humanities and Social Science Research (ICHSSR 2018), Wuxi, China, 25-27 April 2018; Xuemei, D., Huang, C., Zhong, Y., Eds.; Atlantis Press: Paris, France; pp. 569-573.

112. Government of Japan. Outline of the Fifth Science and Technology Basic Plan. Provisional Translation. 2016. Available online: https:/ / www8.cao.go.jp/cstp/english/basic/5thbasicplan_outline.pdf (accessed on 25 March 2019).

113. Hozdić, E. Smart Factory for Industry 4.0: A Review. Int. J. Mod. Manuf. Technol. 2015, 7, 28-35.

114. Yoshino, Y.; Taghizadeh-Hesary, F. Japan's Lost Decade: Lessons for Other Economies; ADBI Working Paper 521; Asian Development Bank Institute: Tokyo, Japan, 2015. Available online: http:/ / www.adbi.org/working-paper/2015/04/08/6590.japan.lost.decade. economies / (accessed on 15 June 2021).

115. Salgues, B. Society 5.0: Industry of the Future, Technologies, Methods and Tools (Technological Prospects and Social Applications); Wiley-ISTE: London, UK, 2018.

116. Pereira, A.G.; Lima, T.M.; Charrua-Santos, F. Industry 4.0 and Society 5.0: Opportunities and Threats. Int. J. Recent Technol. Eng. 2020, 8, 2277-3878.

117. Onday, O. Japan's Society 5.0: Going Beyond Industry 4.0. Bus. Econ. J. 2019, 8, 10-389. [CrossRef]

118. Von Bertalanffy, L. Teoretische Biologie. Bd. 2: Stoffwechsel; Wachstum: Berlin, Germany, 1951.

119. Von Bertalanffy, L. General Systems Theory. Foundations, Development, Applications. Revised Edition. Sixth Printing, 1979 ed.; Braziller: New York, NY, USA, 1968.

120. Wiener, N. Cybernetics: Or Control and Communication in the Animal and the Machine; MIT Press: Cambridge, MA, USA, 1961.

121. François, C. International Encyclopedia of Systems and Cybernetics, 2nd ed.; K. G. Saur Verlag: München, Germany, 2004.

122. Beer, S. Beyond Dispute: The Invention of Team Syntegrity; Wiley: New York, NY, USA; Chichester, UK, $1994 ;$ p. cop.72.

123. Beer, S. Brain of the Firm, 2nd ed.; Jong Wiley \& Sons: New York, NY, USA; Chichester, UK, 1994; p. 73.

124. Crane, A.; Matten, D. COVID-19 and the Future of CSR Research. J. Manag. Stud. 2020. [CrossRef]

125. Beer, S. Platform for Change: A message from Stafford Beer; John Wiley \& Sons: London, UK; New York, NY, USA, 1975.

126. Stokes, P.A. Identity as a Cybernetic Process, Construct and Project. Governance Public Administration. In Proceedings of the Conference by the Cybernetics Society and Metaphorum, Sunderland, UK, January 2004; London School of Economics: London, UK, 2004. 
127. Stokes, P.A. Identity: Articulating cybernetics and sociology. Kybernetes 2016, 35, 124-147. [CrossRef]

128. Stokes, P.A. From Management science to sociology: Cybernetics, finalization and the possibility of a social science. Kybernetes 2007, 36, 420-436. [CrossRef]

129. Beer, S. Brain of the Firm; Allen Lane, The Penguin Press: London, UK, 1972.

130. Guterres, A. Podnebni Ukrepi za Ljudi in Planet_Zdaj je Čas; Dnevnik: Ljubljana, Slovenia, 22 April 2021 ; p. 15.

131. Latapí Agudelo, M.A.; Lára Jóhannsdóttir, L.; Davídsdóttir, B. A literature review of the history and evolution of corporate social responsibility. Int. J. Corp. Soc. Responsib. 2019, 4, 1-23. [CrossRef]

132. CEC European Managers. Sustainable Leadership Guidelines. 2018. Available online: https://www.cec-managers.org/ sustainableleadership/ (accessed on 12 January 2020).

133. Adel, C.; Hussain, M.M.; Mohamed, E.K.A.; Basuony, M. Is corporate governance relevant to the quality of corporate social responsibility disclosure in large European companies? Int. J. Account. Inf. Manag. 2019, 27, 301-332. [CrossRef]

134. Carroll, A. Corporate social responsibility: Evolution of a definitional construct. Bus. Soc. 1999, 38, 268-295. [CrossRef]

135. Mulej, M.; Hrast, A.; Bergant, Ž. (Eds.) Value Added as Business Information from the View of Social Responsibility E Enterprise Sustainability: Conference Proceedings; IRDO: Maribor, Slovenia, 2017.

136. Meseguer-Sánchez, V.; Gálvez-Sánchez, F.J.; López-Martínez, G.; Molina-Moreno, V. Corporate Social Responsibility and Sustainability. A Bibliometric Analysis of Their Interrelations. Sustainability 2021, 13, 1636. [CrossRef]

137. García-Sánchez, I.-M.; García-Sánchez, A. Corporate Social Responsibility during COVID-19 Pandemic. J. Open Innov. Technol. Mark. Complex. 2020, 6, 126. [CrossRef]

138. He, H.; Harris, L. The impact of Covid-19 pandemic on corporate social responsibilitz and marketing philosophy. J. Bus. Res. 2020, 116, 176-182. [CrossRef]

139. Arguinis, H.; Villamor, I.; Gabriel, P.K. Understanding employee responses to COVID-19: A behavioral corporate social responsibility perspective. Manag. Res. 2020, 18, 421-438. [CrossRef]

140. Severo, E.A.; De Guimarães, J.C.F.; Dellarmelin, M.L. Impact of the COVID-19 pandemic on environmental awareness, sustainable consumption and social responsibility: Evidence from generations in Brazil and Portuga. J. Clean. Prod. 2021, $286,124947$. [CrossRef]

141. Situ, H.; Tilt, C.A.; Pi-Shen, S. Corporate Environmental Reporting (CER) in China: A Stakeholder Perspective Conference. In Proceedings of the Australasian Conference on Social and Environmental Accounting Research (A-CSEAR), Sidney, Australia, 11-13 December 2015.

142. Cambridge Institute for Sustainability Leadership-CISL. Cambridge Institute for Sustainability Leadership. Available online: http:/ / www.cisl.cam.ac.uk (accessed on 17 January 2020).

143. Yukl, G. Leadership in Organizations, 6th ed.; Pearson Education: Upper Saddle River, NJ, USA, 2006.

144. Kelloway, K.; Barling, J. Leadership development as an intervention in occupational health psychology. Work Stress 2010, 24, 260-279. [CrossRef]

145. Kouzes, J.M.; Posner, B.Z. Leadership begins with an inner journey. Lead. Lead. 2011, 22-27. [CrossRef]

146. Northouse, P.G. Leadership: Theory E Practice, 6th ed.; Sage: Thousand Oaks, CA, USA, 2013.

147. Šarotar Žižek, S. (Ed.) Osebna Celovitost Človeka (The Personal Integrity of Human Being); Zbirka Well-being; Inštutut za Razvoj Družbene Odgovornosti (IRDO): Maribor, Slovenia, 2015.

148. Ciulla, J.B.; Uhl-Bien, M.; Werhane, P.H. Leadership Ethics; Sage: Los Angeles, CA, USA; London, UK, 2013.

149. Visser, W. Sustainability Leadership-A Force for Change; A thought-piece by the University of Cambridge Programme for Sustainability Leadership; Cambridge: London, UK, 2010.

150. Stefanova, M. Individual leadership as a factor for building a sustainable and resilient company. In Social Responsibility and Current Challenges 2020: Personal and Social Responsibility for Sustainable Future. Proceedings of 15th IRDO International Science and Business Conference Social Responsibility and Current Challenges 2020: Personal and Social Responsibility for Sustainable Future, Maribor, Slovenia, 4-5 June 2020.

151. Mahmood, F.; Qadeer, F.; Abbas, Z.; Hussain, I.; Saleem, M.; Hussain, A.; Aman, J. Corporate Social Responsibility and Employees' Negative Behaviors under Abusive Supervision: A Multilevel Insight. Sustainability 2020, 12, 2647. [CrossRef]

152. Merhar, V. Reševanje krize kapitalizma kot družbenoekonomskega sistema zahteva reafirmacijo zamolčanih ekonomskih teorii. In Družbeno Odgovorna Družba Nastaja; Mulej, M., Ed.; IRDO: Ljubljana, Slovenia, 2017.

153. Damijan, J.P. Zakaj bo Biden novi Roosevelt; Dnevnik: Ljubljana, Slovenia, 9 April 2021; p. 14. 